\title{
In-Can Melting \\ Demonstration of Wastes \\ From the Idaho Chemical \\ Processing Plant
}

W. J. Bjorklund

L. A. Chick

H. H. Hollis
G. B. Mellinger

T. A. Nelson

L. L. Petkus

July 1980

Prepared for the U.S. Department of Energy under Contract DE-AC06-76RLO 1830

Pacific Northwest Laboratory

Operated for the U.S. Department of Energy

by Battelle Memorial Institute 


\title{
NOTICE
}

This report was prepared as an account of work sponsored by the United States Government. Neither the United States nor the Department of Energy, nor any of their employees, nor any of their contractors, subcontractors, or their employees, makes any warranty, express or implied, or assumes any legal liability or responsibility for the accuracy. completeness or usefulness of any information, apparatus, product or process disclosed, or represents that its use would not infringe privately owned rights.

The views, opinions and conclusions contained in this report are those of the contractor and do not necessarily represent those of the United States Government or the United States Department of Energy.

PACIFIC NORTHWEST LABORATORY

operated by

BATTELLE

for the

UNITED STATES DEPARTMENT OF ENERGY

Under Contract DE-AC06-76RLO 1830

\author{
Printed in the United States of America \\ Available from \\ National Technical Information Service \\ United States Department of Commerce \\ 5285 Port Royal Road \\ Springfield, Virginia 22151
}

Price: Printed Copy 5

$\because$ Microfiche $\$ 3.00$

NTIS

-Pages Selling Price

$\begin{array}{ll}001-025 & \$ 4.00 \\ 026-050 & \$ 4.50 \\ 051-075 & \$ 5.25 \\ 076-100 & \$ 6.00 \\ 101-125 & \$ 6.50 \\ 126-150 & \$ 7.25 \\ 151-175 & \$ 8.00 \\ 176-200 & \$ 9.00 \\ 201-225 & \$ 9.25 \\ 226-250 & \$ 9.50 \\ 251-275 & \$ 10.75 \\ 276-300 & \$ 11.00\end{array}$


PNL -3405

UC -70

33679000544827

IN-CAN MELTING DEMONSTRATION OF WASTES

FROM THE IDAHO CHEMICAL PROCESS ING PLANT

W. J. Bjorklund

L. A. Chick

H. H. Hollis

G. B. Mellinger

T. A. Nelson

L. L. Petkus

July 1980

Prepared for

the U.S. Department of Energy

under Contract DE-AC06-76RL0 1830

Pacific Northwest Laboratory

Richland, Washington 99352 


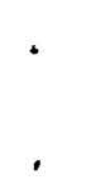

. 


\section{SUMMARY}

The immobilization of Idaho Chemical Processing Plant (ICPP) zirconia calcine using Idaho glass composition (ICPP-127) was evaluated at Pacific Northwest Laboratory (PNL) in two engineering-scale in-can melter tests. The glass was initially characterized in the laboratory to verify processing parameters. Glass was then produced in a pilot-scale melter and then in a full-scale melter to evaluate the processing and the resultant product. Potential corrosion problems were ident ified with the glass and some processing problems were encountered, but neither are insurmountable. The product is a durable leachresistant glass. The glass appears to be nonhomogeneous, but chemically it is quite uniform. 

. 


\section{CONTENTS}

SUMMARY

INTRODUCTION

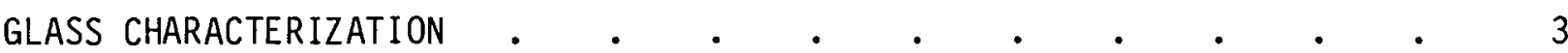

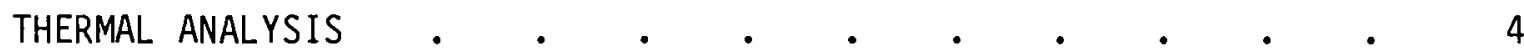

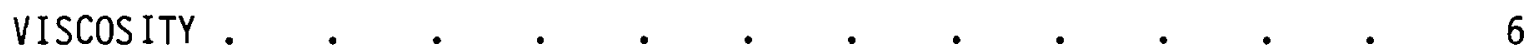

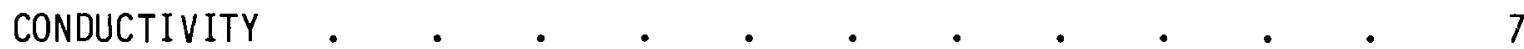

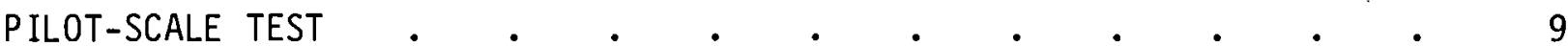

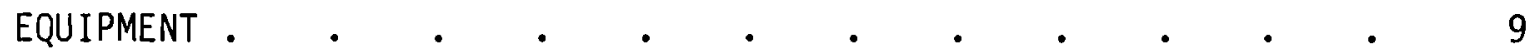

TEST • •

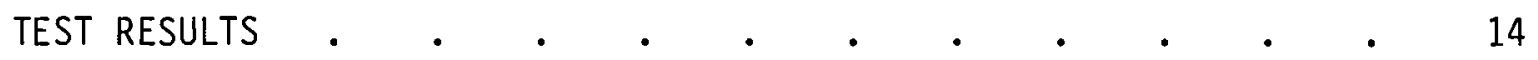

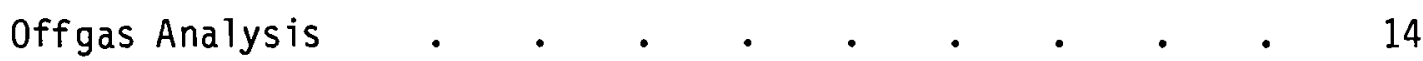

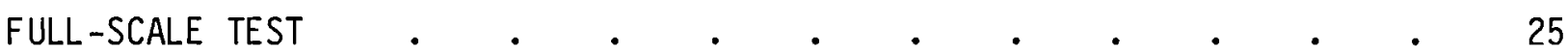

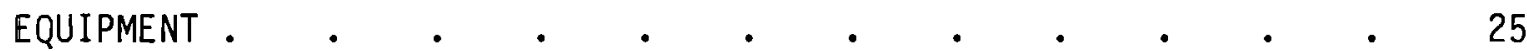

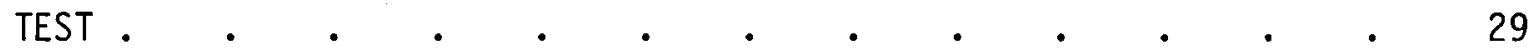

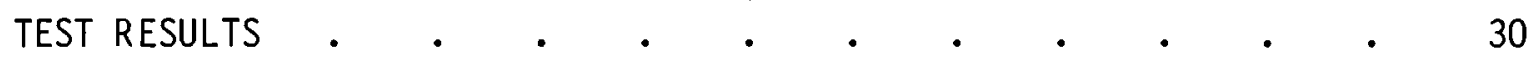

PRODUCT EVALUATION

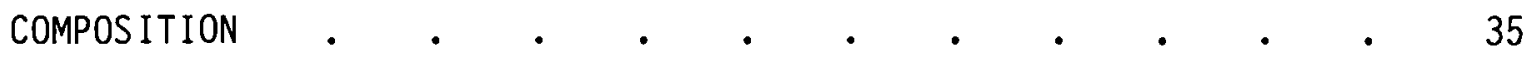

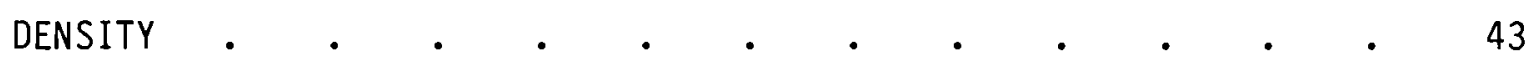

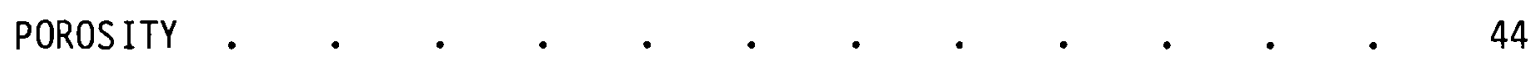

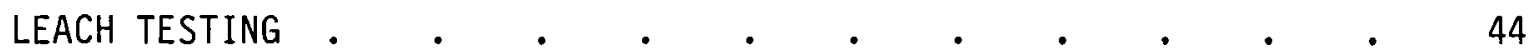

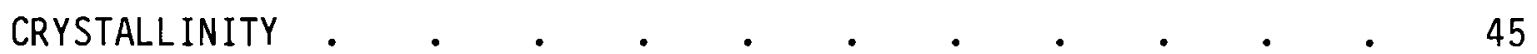

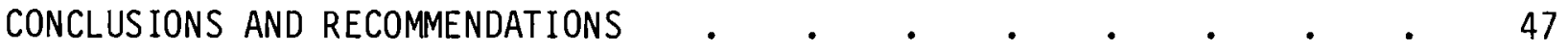

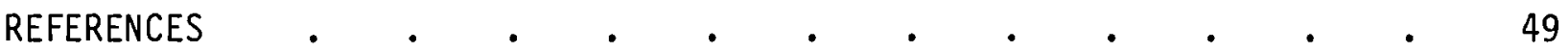




\section{FIGURES}

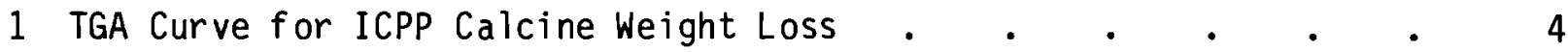

2 DTA Thermogram for ICPP Glass . $\quad$. $\quad$. $\quad$. $\quad$. 5

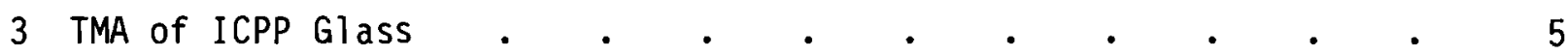

4 Viscosity of ICPP Sample Used in ICM-32 . . . . . . . 6

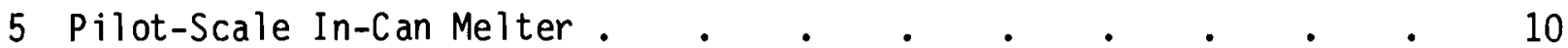

6 Schematic Diagram Pilot-Scale In-Can Melter . . . . . . . 11

7 Weigh Belt Feeder used For Pilot-Scale ICM Run _ . . . . 12

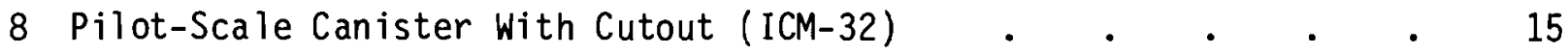

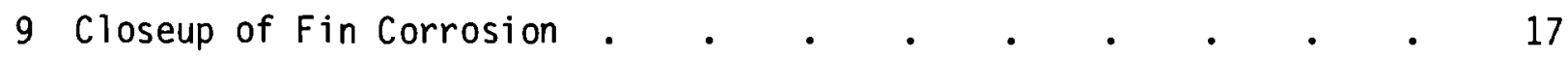

10 ICM-32 Canister Wall Film Corrosion (304L SS) .

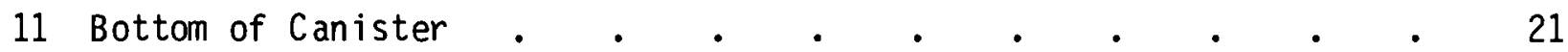

12 Schematic Diagram of Caustic Sampler System . . . . . . 23

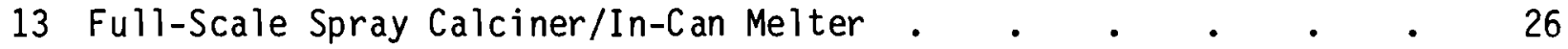

14 Thermocouple (TC) Placement in Full-Scale Canister . $\quad$ • . $\quad$ - 27

15 Full-Scale In-Can Melter Connecting Section Mechanism . • . 28

16 Calcine Coating Inside ICM Connecting Section . • • • . 31

17 Material Accumulated In ICM Connecting Section _ . • • • 32

18 Micrograph ICM - 32 Glass . . . . . . . . . . . . 39

19 Microprobe Trace for Blue Glass $\quad$. $\quad$. $\quad$. $\quad$. $\quad$. $\quad$. 41

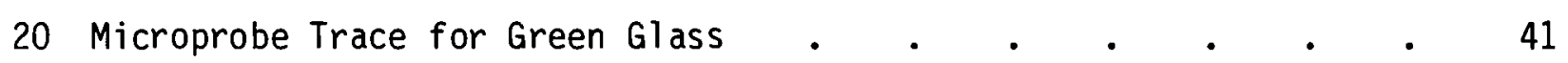

21 Microprobe Trace for Red Glass ..$\quad$. . . . . . . . . 42

22 Microprobe Trace for Brown Glass . . . . . . . . . . 42 


\section{TABLES}

1 Induction-Coupled Plasma (ICP) Spectroscopy of Glass Components . 3

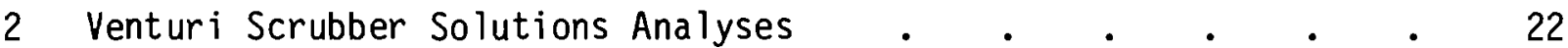

3 Analys is by Induction-Coupled Plasma Spectroscopy of Connecting Section Coating . . . . . . . . . 33

4 Chemical Composition Of ICPP ICM-32 Glass . . . . . . 35

5 Induction-Coupled Plasma (ICP) Analysis of ICPP Waste Glass . . 36

6 Full-Scale Canister Inductive-Coupled Plasma (ICP) Analysis . . 37

7 Chemical and Physical Properties of ICPP Waste Glass in Pilot-Scale Canister . . . . . . . . . . . . 43

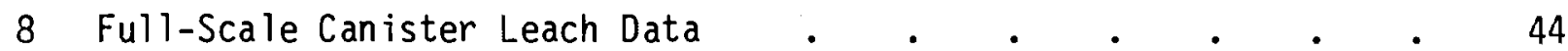


-

. 


\section{INTRODUCTION}

The Idaho Chemical Processing Plant (ICPP), operated by Exxon Nuclear Idaho Company, Inc., at the Idaho National Engineering Laboratory (INEL), reprocesses defense-type nuclear fuel. The resulting high-level acidic waste solutions are stored for a period in underground tanks and then are converted through a fluidized-bed process to a dry granular calcine material. This calcine is currently stored on-site at the ICPP in stainless steel bins (Gombert et al. 1979). Conversion of this material to a less dispersible and more leach-resistant form may be required should permanent storage or disposal at a Federal repository be necessary.

One of several waste-management alternatives being investigated is vitrification using an in-can melting process. Recently, successful pilot-scale and full-scale demonstrations of this vitrification concept were completed at PNL using equipment located at the 300 Area Engineering Development Laboratory. Simulated zirconia waste calcine was shipped from INEL to PNL where it was mixed with a glass-former compound and fed to the in-can melting process.

A pilot-scale run of the in-can melting process was followed by a fullscale run of the process. During the full-scale run a vitrified product was produced in a canister $213.36 \mathrm{~cm}$ long and $60.96 \mathrm{~cm}$ dia. The canister contained about $1100 \mathrm{~kg}$ of the waste glass. The vitrified product was very durable and leach resistant, demonstrating the feasibility of using the in-can melting process for vitrification of this type waste. 



\section{GLASS CHARACTERIZATION}

Before attempting any engineering-scale melts, some laboratory melts were made to assess handling and to make glass for use in some of the tests. These melts produced a satisfactory proposed glass which was put through a series of analyses to characterize the product. Constituents of the calcine and the frit were analyzed. The batch was blended from the fluidized bed particles, filter fines and frit. The blend was $66.6 \%$ frit, $23.5 \%$ particles, and $9.9 \%$ fines. These three product constituents were analyzed by Induction-Coupled Plasma (ICP) Spectroscopy. The metal ions in their assumed states are listed in Table 1. Each of the tests are described below:

TABLE 1. Induction-Coup led Plasma (ICP) Spectroscopy of Glass Components

\begin{tabular}{|c|c|c|c|c|c|c|c|}
\hline $\begin{array}{l}\text { Metal } \\
\text { Ions }\end{array}$ & Frit (ICP-127) & $\begin{array}{c}\text { Calcine } \\
\text { Particles } \\
\text { wtx } \\
\end{array}$ & $\begin{array}{c}\text { Calcine } \\
\text { Fines } \\
\text { wtx } \\
\end{array}$ & $\begin{array}{l}\text { Assumed } \\
\text { Oxide } \\
\end{array}$ & $\begin{array}{c}\text { Frit (ICP-127) } \\
\text { wt\% } \\
\end{array}$ & $\begin{array}{c}\text { Calcine } \\
\text { Particles } \\
\text { wt\% } \\
\end{array}$ & $\begin{array}{c}\text { Calcine } \\
\text { Fines } \\
\text { wt\% } \\
\end{array}$ \\
\hline Al & - & 7.07 & 7.05 & $\mathrm{Al}_{2} \mathrm{O}_{3}$ & -- & 13.4 & 13.3 \\
\hline B & 2.69 & 2.12 & 1.06 & $\mathrm{~B}_{2} \mathrm{O}_{3}$ & 8.65 & 6.83 & 3.42 \\
\hline $\mathrm{Zr}$ & -- & 16.7 & 19.4 & $\mathrm{ZrO}_{2}$ & -- & 22.5 & 26.2 \\
\hline \multirow[t]{2}{*}{$\mathrm{Ca}$} & .08 & 27.0 & 25.7 & $\mathrm{Ca} 0^{f a}$ & .11 & 3.0 & 3.0 \\
\hline & & & & $\mathrm{CaF}$ & -- & 48.4 & 45.9 \\
\hline $\mathrm{Cr}$ & -- & .4 & .42 & $\mathrm{Cr}_{2} \mathrm{O}_{3}$ & -- & .58 & .61 \\
\hline $\mathrm{Cu}$ & 1.75 & .13 & .11 & $\mathrm{CuO}$ & 2.19 & .17 & .14 \\
\hline $\mathrm{Fe}$ & -- & .21 & .49 & $\mathrm{Fe}_{2} \mathrm{O}_{3}$ & -- & .3 & .7 \\
\hline $\mathrm{Na}$ & 9.85 & -- & .29 & $\mathrm{Na}_{2} \mathrm{O}$ & 13.3 & -- & .39 \\
\hline $\mathrm{Mg}$ & -- & .14 & .17 & $\mathrm{MgO}$ & -- & .23 & .28 \\
\hline $\mathrm{Si}$ & 33.7 & .16 & .13 & $\mathrm{SiO}_{2}$ & 72.0 & .33 & .27 \\
\hline $\mathrm{Sr}$ & -- & .58 & .69 & Sro & -- & .68 & .81 \\
\hline $2 n$ & -- & 3.13 & .16 & $2 n 0$ & -- & 3.9 & .2 \\
\hline \multirow[t]{2}{*}{$\mathrm{Li}$} & 2.82 & -- & -- & $\mathrm{Li}_{2} \mathrm{O}$ & 6.06 & -- & -- \\
\hline & & & & & 102.3 & 100.3 & $\overline{95.2}$ \\
\hline
\end{tabular}

(a) Assumed $\mathrm{Ca0}$ at $3 \mathrm{x}$ to calculate CaF. 
THERMAL ANALYSIS

Thermal analysis was carried out on ICPP calcine and ICPP waste glass. The samples were analyzed by using thermogravimetric analysis (TGA), differential thermal analysis (DTA) and thermomechanical analysis (TMA).

A TGA curve for ICPP calcine is shown in Figure 1 . Nearly $10 \mathrm{mg}$ of sample were loaded onto a platinum pan and then heated from ambient temperature to $85^{\circ} \mathrm{C}$ in an air atmosphere at a rate of $10^{\circ} \mathrm{C} / \mathrm{min}$. The calcine showed a minor weight loss of $2.6 \mathrm{wt} \%$ when the temperature ranged from $25^{\circ} \mathrm{C}$ to $800^{\circ} \mathrm{C}$. No quantities of hydrates or residual nitrates were observed.

A DTA scan was made of the ICPP waste glass at a sensitivity of $1^{\circ} \mathrm{C} / \mathrm{in}$. at a rise of $10^{\circ} \mathrm{C} / \mathrm{min}$. The DTA thermogram is illustrated in Figure 2. The $\mathrm{glass}$ showed endothermic reactions at $475^{\circ} \mathrm{C}$ and $680^{\circ} \mathrm{C}$. Upon completion of the DTA, it was observed that the waste glass attacked the 4-mm glass tube. It is believed that the fluoride present in the waste glass reacted with the glass tube causing the tube to rupture. However, this incident did not have an adverse effect on the DTA experiment.

The thermal expansion curve is presented in Figure 3 for ICPP waste glass. The sample glass cylinder ( $1 / 4$ in. $\times 1 / 4$ in.) was heated from room

THERMAL PROPERT IES OF ICPP CALCINE AND GLASS

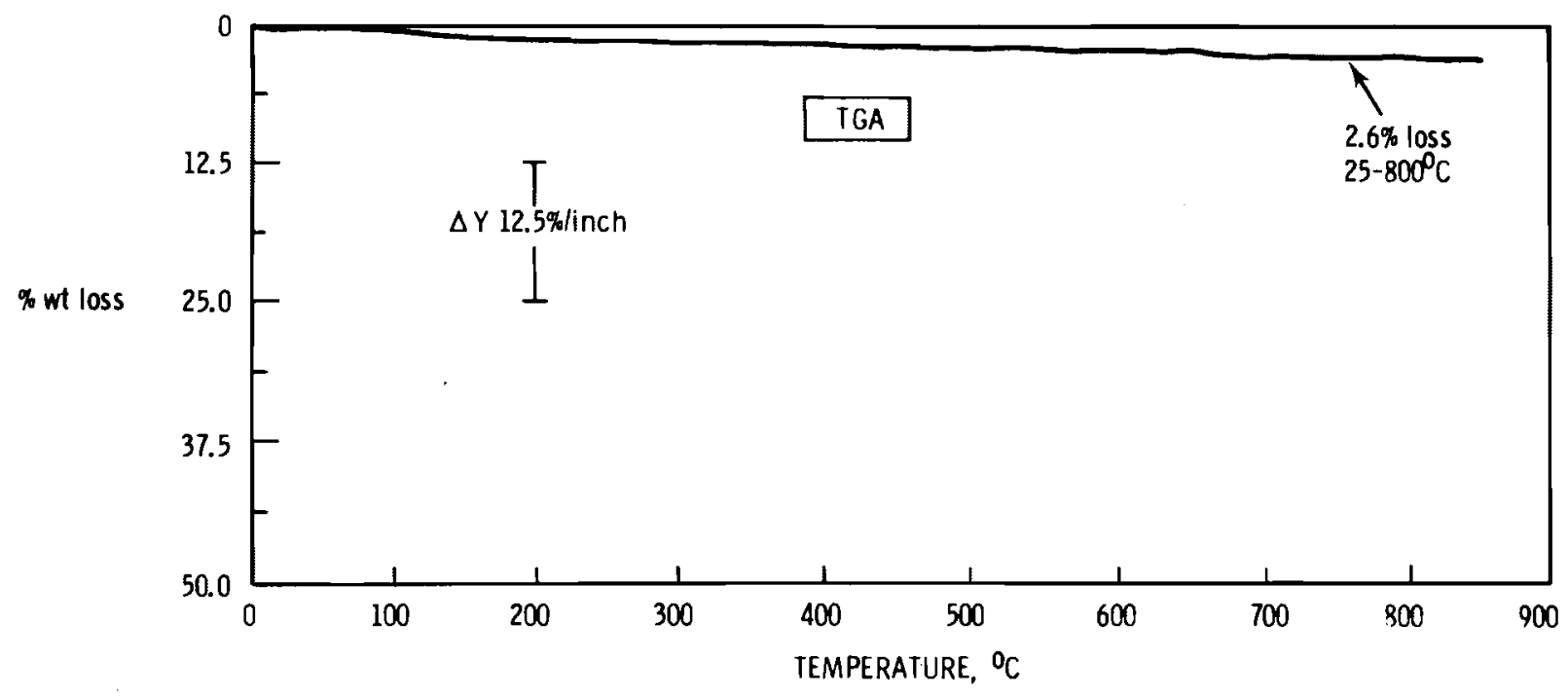

FIGURE 1. TGA Curve for ICPP Calcine Weight Loss 


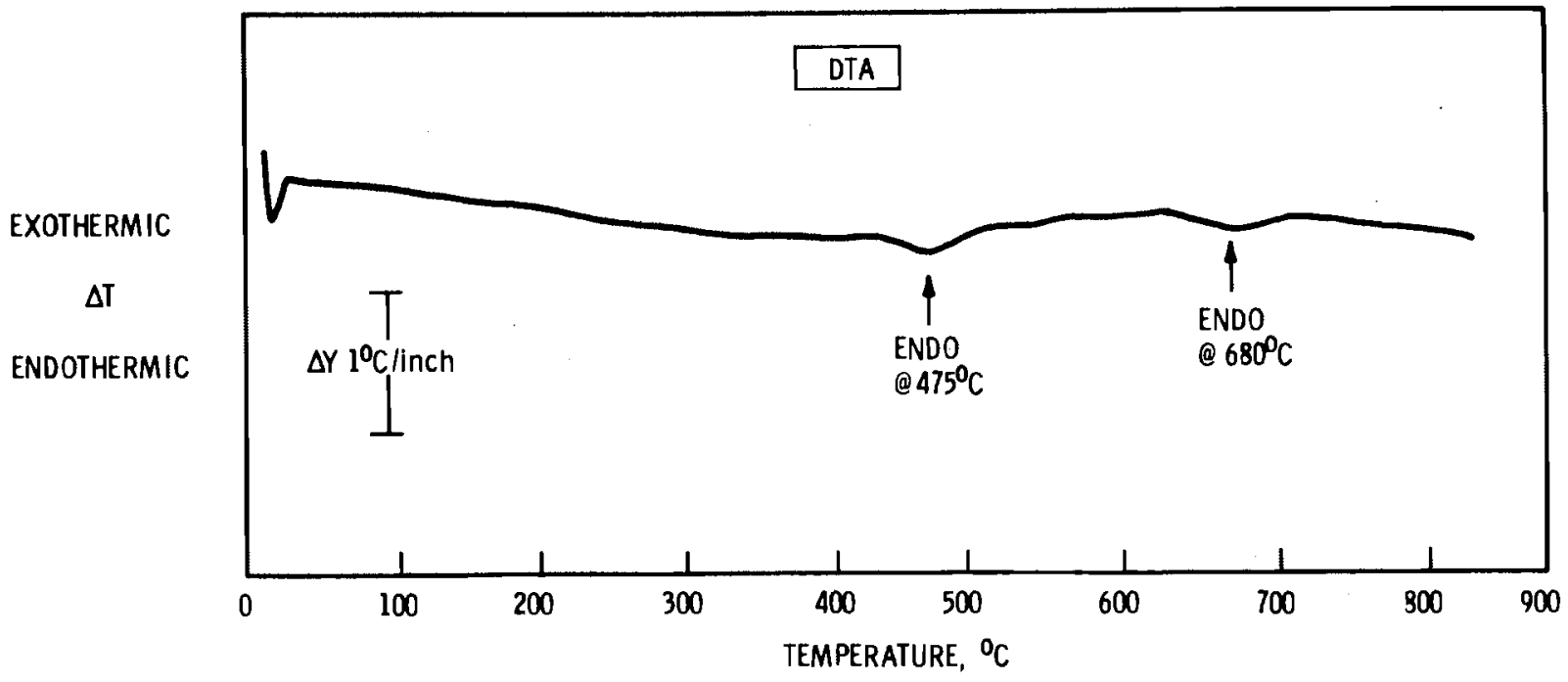

FIGURE 2. DTA Thermogram for ICPP Glass

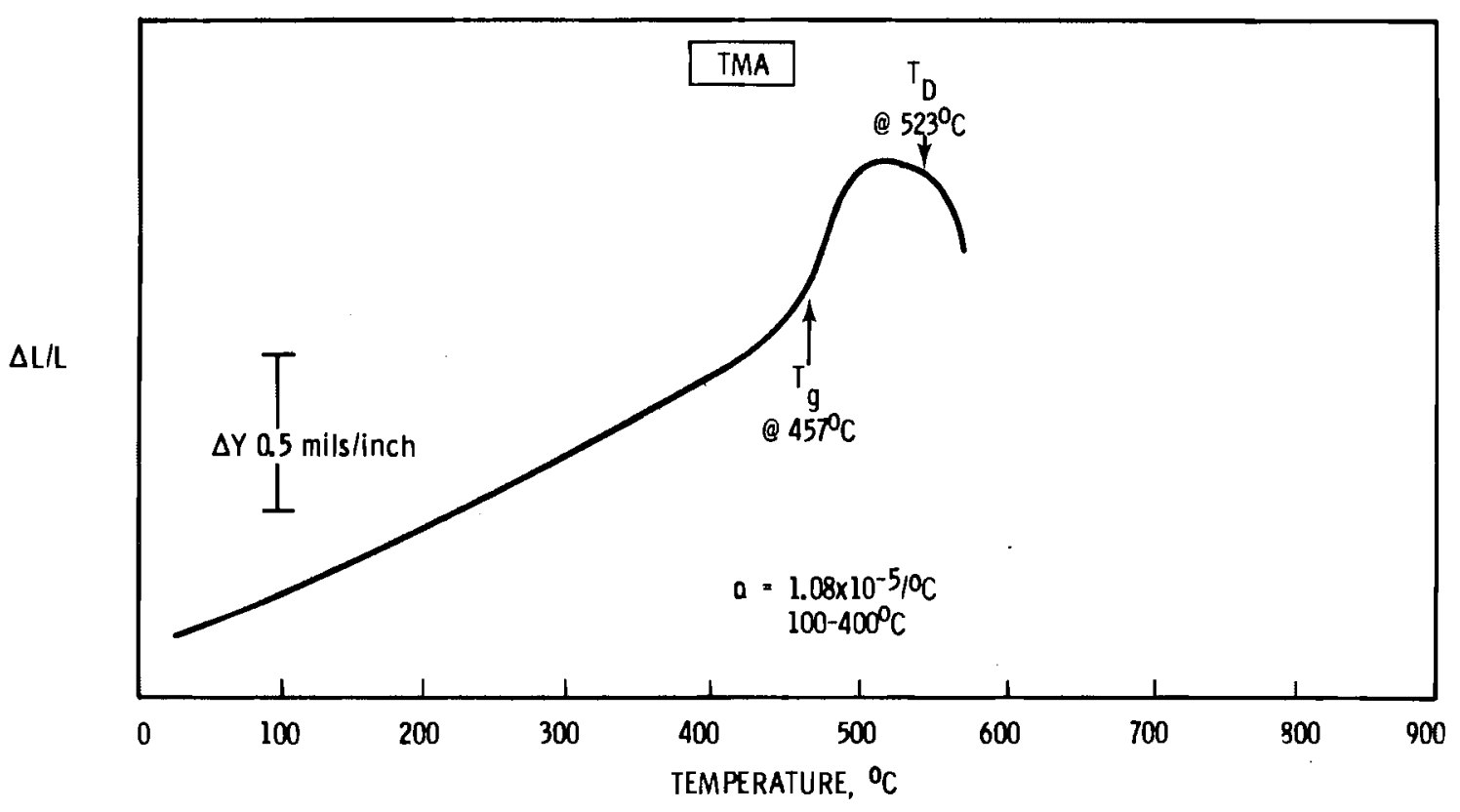

FIGURE 3. TMA of ICPP Glass 
temperature to $600^{\circ} \mathrm{C}$ at a rate of $5^{\circ} \mathrm{C} / \mathrm{min}$. The glass transition and the softening point were obtained by extrapolating the two linear portions of the expansion scan. The glass transition and softening point were determined by the temperature intersection. The value $5 \times 10^{-7} \mathrm{in} . /^{\circ} \mathrm{C}$ was added to the expansion results due to the dimensional change of the silica dilatometer tube at temperatures ranging from $25^{\circ} \mathrm{C}$ to $600^{\circ} \mathrm{C}$. This sample glass has a higher thermal expansion than typical waste glasses that have been tested. Typical waste glasses display a thermal expansion which ranges from $7 \times 10^{-6} /{ }^{\circ} \mathrm{C}$ to $8 \times 10^{-6} /{ }^{\circ} \mathrm{C}$ at temperatures from $100^{\circ} \mathrm{C}$ to $500^{\circ} \mathrm{C}$. Since the thermal expansion of ICPP glass $\left(1.08 \times 10^{-5} /{ }^{\circ} \mathrm{C}\right)$ is close to stainless steel, it most likely could avoid any major microcracking in the glass.

\section{VISCOSITY}

The viscosity of a sample of the feed for ICM-32 (pilot-scale run) is shown in Figure 4 as a single slope between $950^{\circ} \mathrm{C}$ and $1150^{\circ} \mathrm{C}$. This slope

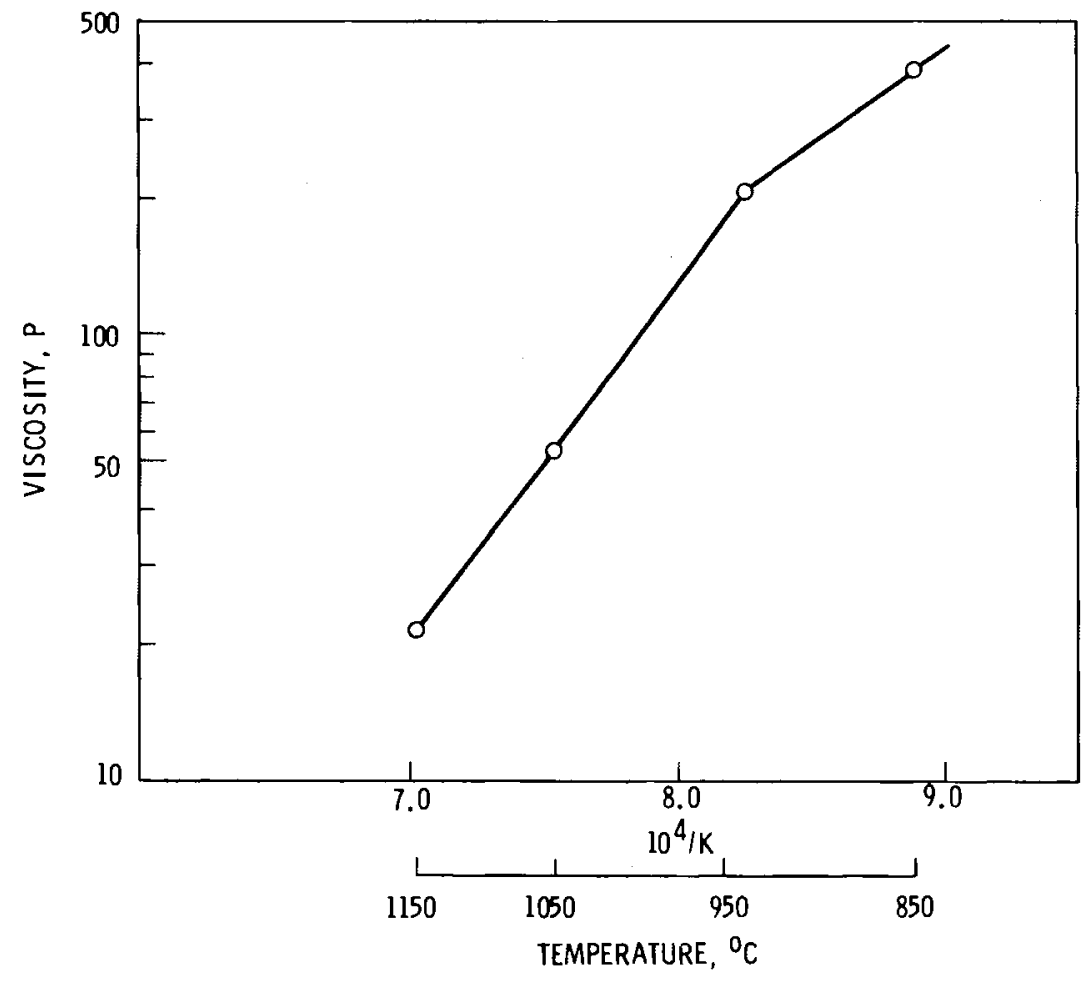

FIGURE 4. Viscosity of ICPP Sample Used in ICM-32 
indicates that no sudden changes, such as precipitation of crystallites or other phase separation, are occurring in this temperature range. If such changes are occurring, they are happening uniformly over the entire temperature range. Below $950^{\circ} \mathrm{C}$, however, a change does occur which probably is related to the phase behavior of this glass.

\section{$\underline{\text { CONDUCTIVITY }}$}

The electrical conductivity of the melter feed was measured at a frequency of $1000 \mathrm{~Hz}$. The values were $0.20(\mathrm{ohm}-\mathrm{cm})^{-1}$ at $1050^{\circ} \mathrm{C}$ and $0.32(\mathrm{ohm}-\mathrm{cm})^{-1}$ at $1235^{\circ} \mathrm{C}$. 


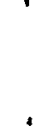




\section{PILOT-SCALE TEST}

The pilot-scale equipment is presently arranged to test the close-coupled spray calciner/in-can melter concept. Because of this feature, the melter furnace is vented through the spray calciner to the offgas treatment. Since calcine was shipped from ICPP, use of the spray calciner was not required; however, the equipment arrangement was maintained to accommodate offgas handling. In this test the spray calciner was kept at $200^{\circ} \mathrm{C}$ to keep the sintered metal filters warm to prevent condensation on the filters.

\section{EQUIPMENT}

The in-can melter (ICM) consists of a single-zone, resistance-heated furnace (see Figures 5 and 6 ). The furnace has a power rating of $70 \mathrm{~kW}$ which is controlled from a thermocouple located in the middle of the furnace heating zone (Blair 1979). The heating cavity is $139.7 \mathrm{~cm}$ (55 in.) long with a 49.5-cm- (19-1/2-in.) dia top opening. The furnace was operated at $1070^{\circ} \mathrm{C}$ for the test.

A gravimetric feeder is used to meter the preblended feed into the melter. The feeder uses a weighed belt and a variable-speed drive motor to deliver up to $50 \mathrm{~kg} / \mathrm{h}$ feed with $\pm 1 \%$ accuracy. See Figure 7 . The feedrate is commenced at $40 \mathrm{~kg} / \mathrm{h}$ to test the fastest rate. The feedrate is then adjusted, as necessary, to fill the canister to the top of the fins.

The canister is suspended from lifting ears inside the cavity and hung from a load cell used to monitor the weight of the canister during filling. The ICM canister, which will be filled to a level of $3 \mathrm{ft}$, is a $5-\mathrm{ft}$ section of 8-in.-dia Schedule 10, 304L stainless steel pipe with a flat bottom. An eight-fin internal assembly, also fabricated from 304L stainless steel, is inserted into the canister up to the $3-\mathrm{ft}$ level to promote heat transfer into the canister for melting. It defines the fill volume of the canister. The fin assembly also facilitates heat dissipation for cooling and storage. The fill section of the canister is equipped with six thermocouples attached to the 1/4-in.-thick fins and positioned every 6 in. to monitor the centerline 


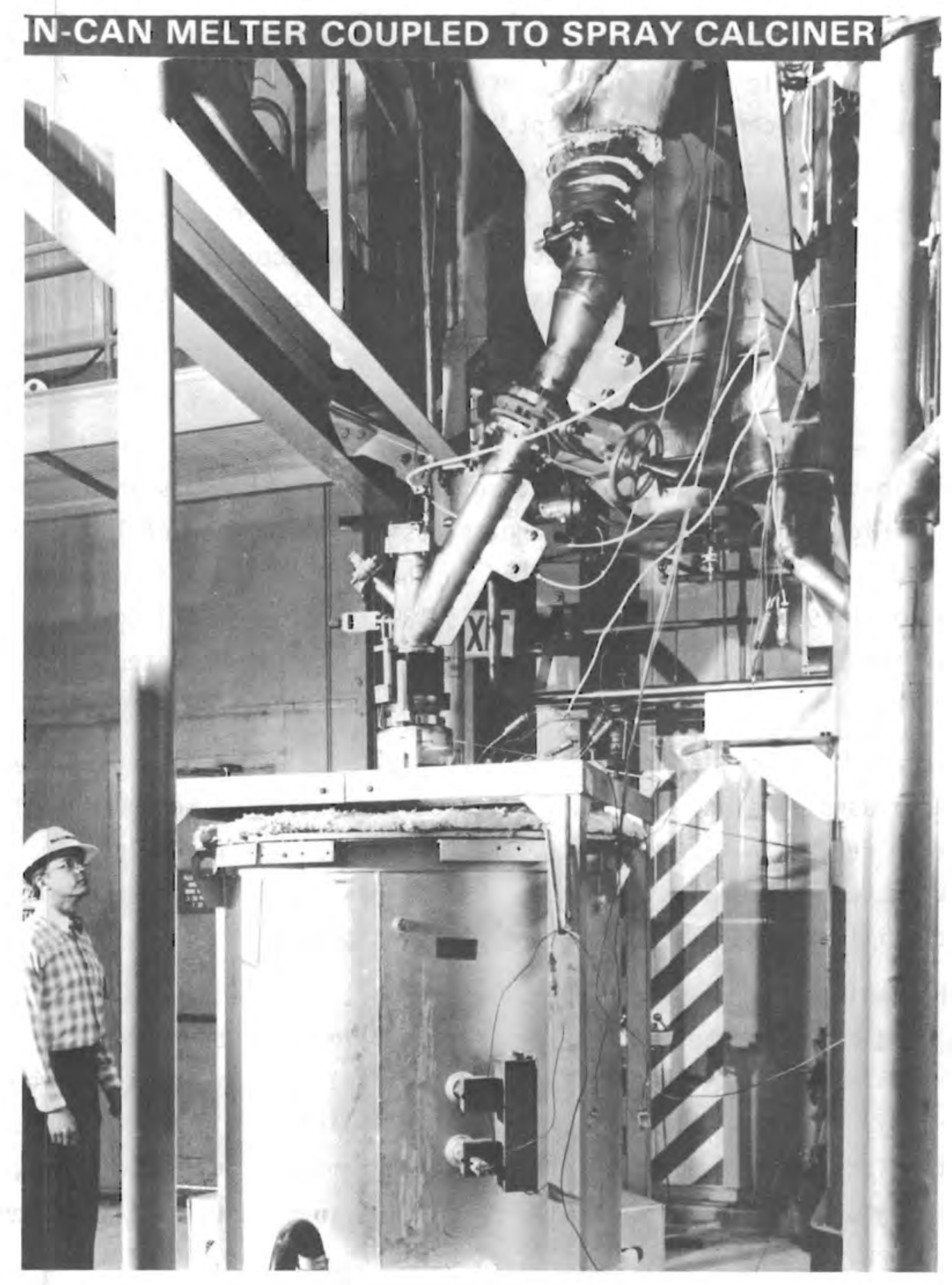

FIGURE 5. Pilot-Scale In-Can Melter 


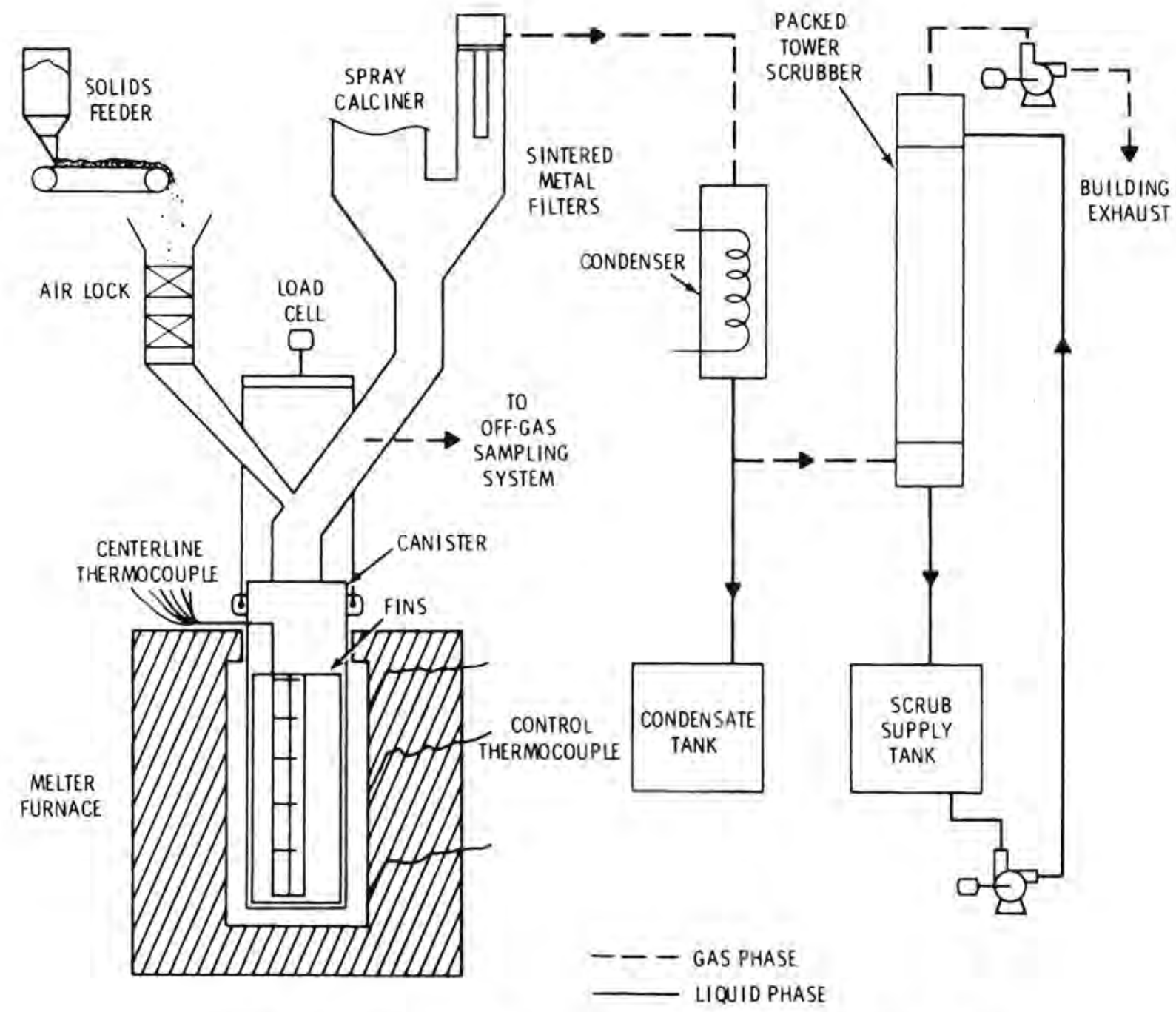

FIGURE 6. Schematic Diagram Pilot-Scale In-Can Melter

temperature in the canister. Three thermocouples are located on the wall of the canister. The thermocouples give an indication of melt level in the canister.

The offgas system is comprised of fifteen, $65-\mu \mathrm{m}$ sintered metal filters, a condenser, and a venturi scrubber in the auxiliary offgas treatment system. The surface area of the sintered metal filters is $1.3 \mathrm{~m}^{2}\left(15 \mathrm{ft}^{2}\right)$. 


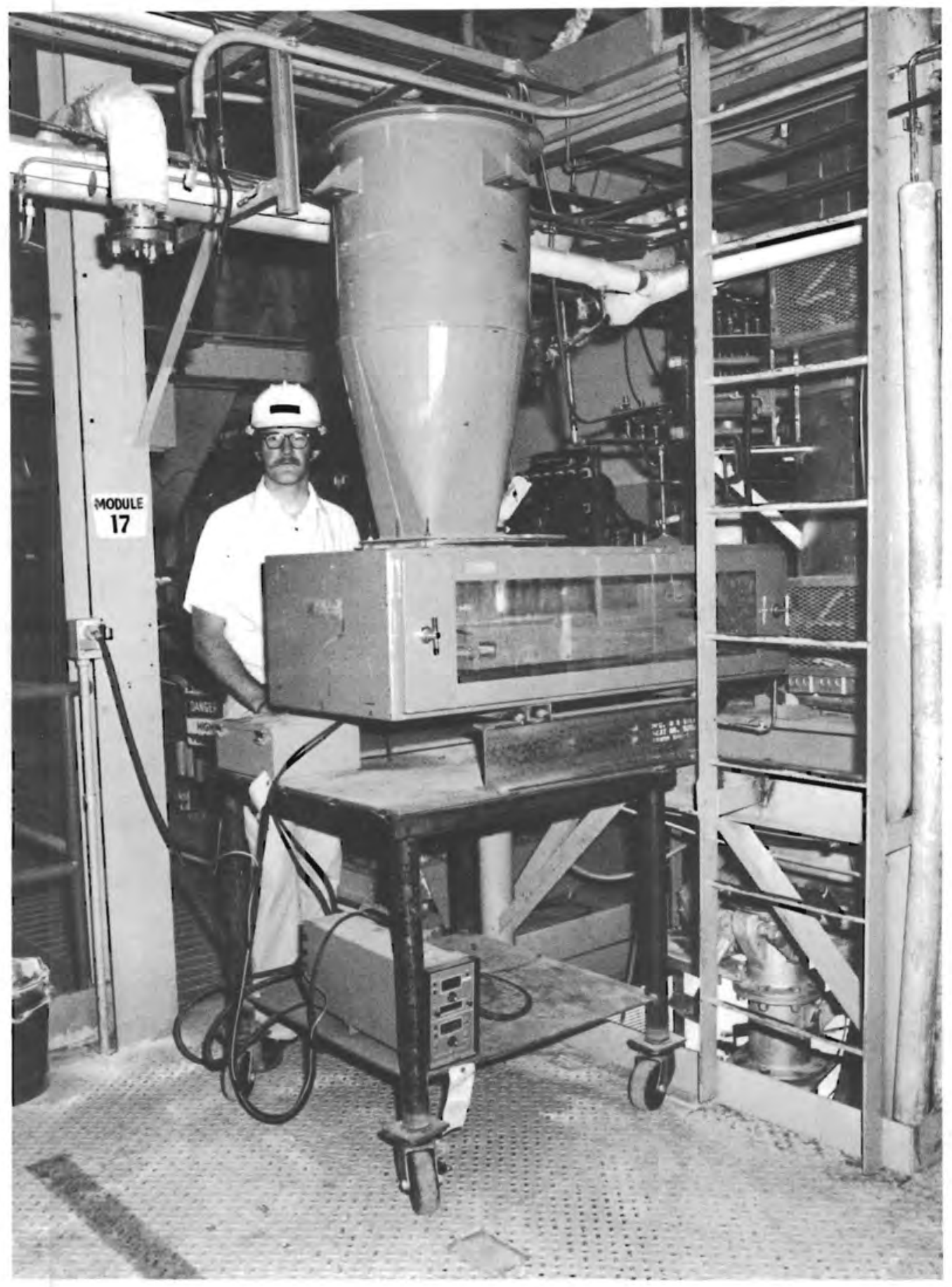

FIGURE 7. Weigh Belt Feeder used For Pilot-scale ICM Run 
The pressure above the canister is maintained at about -2 in. $\mathrm{H}_{2} \mathrm{O}$. The filters are equipped with a pulsed-air blowback system to remove any excess filtercake if pressure drop through the filters becomes excessive ( 5 to 8 in. $\left.\mathrm{H}_{2} \mathrm{O}\right)$.

During the test, a laboratory gas scrubber is used to scrub a measured offgas stream from the melter. Gas is pulled (by means of a vacuum pump) from the connecting section through a rotameter, a filter, and the scrubber which is filled with $0.5 \mathrm{M}$ sodium hydroxide. The purpose of the scrubber is to measure any volatilized fluoride coming from the calcine. As another check for fluorine corrosion, two 304 stainless steel corrosion coupons are hung above the canister.

$\underline{\text { TEST }}$

Filling a canister in the in-can melter run does not provide dramatic display or a large quantity of data. The process is very simple. Feed is metered into the canister, the furnace controller holds the furnace temperature at $1070^{\circ} \mathrm{C}$ and progress of the run is monitored by the thermocouples in the canister.

During this run the thermocouples registered temperatures that were much lower than normal in the active zone (the rising interface between melted glass and unmelted frit and calcine). Such a drop in temperature usually means that the feedrate is too high and should be cut back. However, in this run, even though the temperatures were low, there was no inventory of unmelted feed in the canister. When the feeder was stopped, the rest of the feed in the canister would melt and the temperature would return to normal in 10 to $15 \mathrm{~min}$. which is considered normal. The reason for this behavior is unclear, but it is probable that higher feedrates could have been sustained in the run.

The run lasted $8 \mathrm{~h}$. A pilot-scale canister was filled to almost $91 \mathrm{~cm}$ (36 in.) with $65 \mathrm{~kg}$ of glass. The maximum feedrate achieved was $30 \mathrm{~kg} / \mathrm{h}$, with an average of $15 \mathrm{~kg} / \mathrm{h}$. The furnace was held at $1070^{\circ} \mathrm{C}$ during the test and was at an average power of $18 \mathrm{~kW}$. The scrubber and the condenser were sampled each hour; however, there was not enough condensate collected to analyze. Also, the lab scrubber was operated for $3 \mathrm{~h}$ at $1 \mathrm{scfh}$. 
Upon completion of the feeding period, the glass was allowed to soak for $1 \mathrm{~h}$ at $1070^{\circ} \mathrm{C}$ to make sure all reactions had taken $\mathrm{place}$. After the soak period, the furnace was shut off and allowed to cool. The cooldown rate from $1050^{\circ} \mathrm{C}$ to $450^{\circ} \mathrm{C}$ was $50^{\circ} \mathrm{C} / \mathrm{h}$.

\section{$\underline{\text { TEST RESULTS }}$}

After cooldown, the canister was disconnected from the connection section and removed from the furnace. At that time it was noticed that apparently calcine fines had collected on the lower end of the connection section at the canister. Laboratory analysis later confirmed the calcine fines with small amounts of boron at the cooler areas of the connection section. Boron is known to volatilize easily from the frit. A portion of the side of the cooled canister was cut away and removed (see Figure 8) to collect samples. Upon removal of part of the canister, it was noticed that visible metal loss had occurred on the fins, and the metal of the fins and the canister wall had discolored due to corrosion (see Figures 9 and 10). Visible discoloration was also evident when a portion was removed from the bottom of the canister (see Figure 11).

\section{Offgas Analysis}

The volume of offgas generated from melting the frit and calcine was sma11. During the pilot-scale run the total flow of offgas was less than 8 scfm, including in-leakage. Major components of the generated gas were $0_{2}$, $\mathrm{NO}_{x}$, fluoride and calcium. Of these components, the most interesting is fluoride because it presents a potential corrosion problem to the offgas system.

Chemical analysis of the laboratory caustic scrubber and the process verturi scrubber showed little or no fluoride carryover in the offgas (see Table 2). The constant calcium values in the scrub samples indicated that no volatile fluoride was being trapped in the scrub solution. Free fluoride would exceed the solubility product of $\mathrm{CaF}_{2}$ and cause a decrease of calcium in solution. The calcium values also indicated that while $\mathrm{CaF}_{2}$ was physically carried over to the offgas, it was not soluble in the scrub 


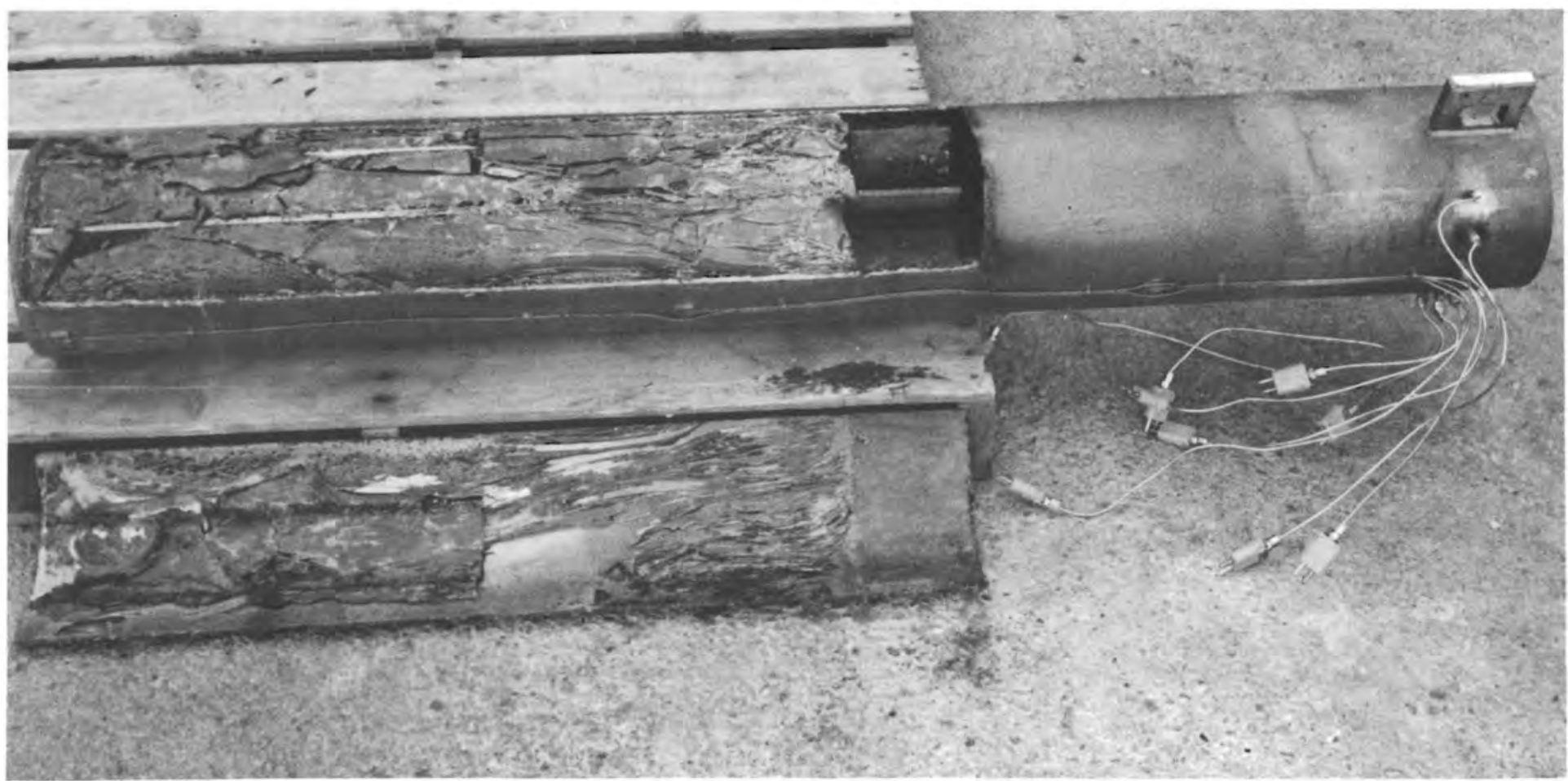

FIGURE 8. Pilot-Scale Canister With Cutout (ICM-32) 


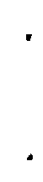




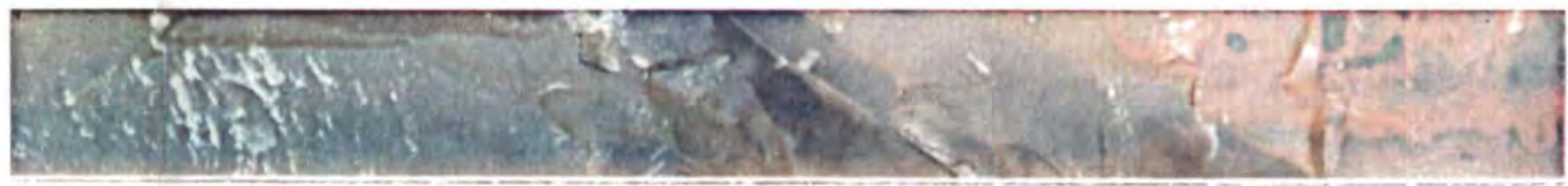

\section{\%ัต}

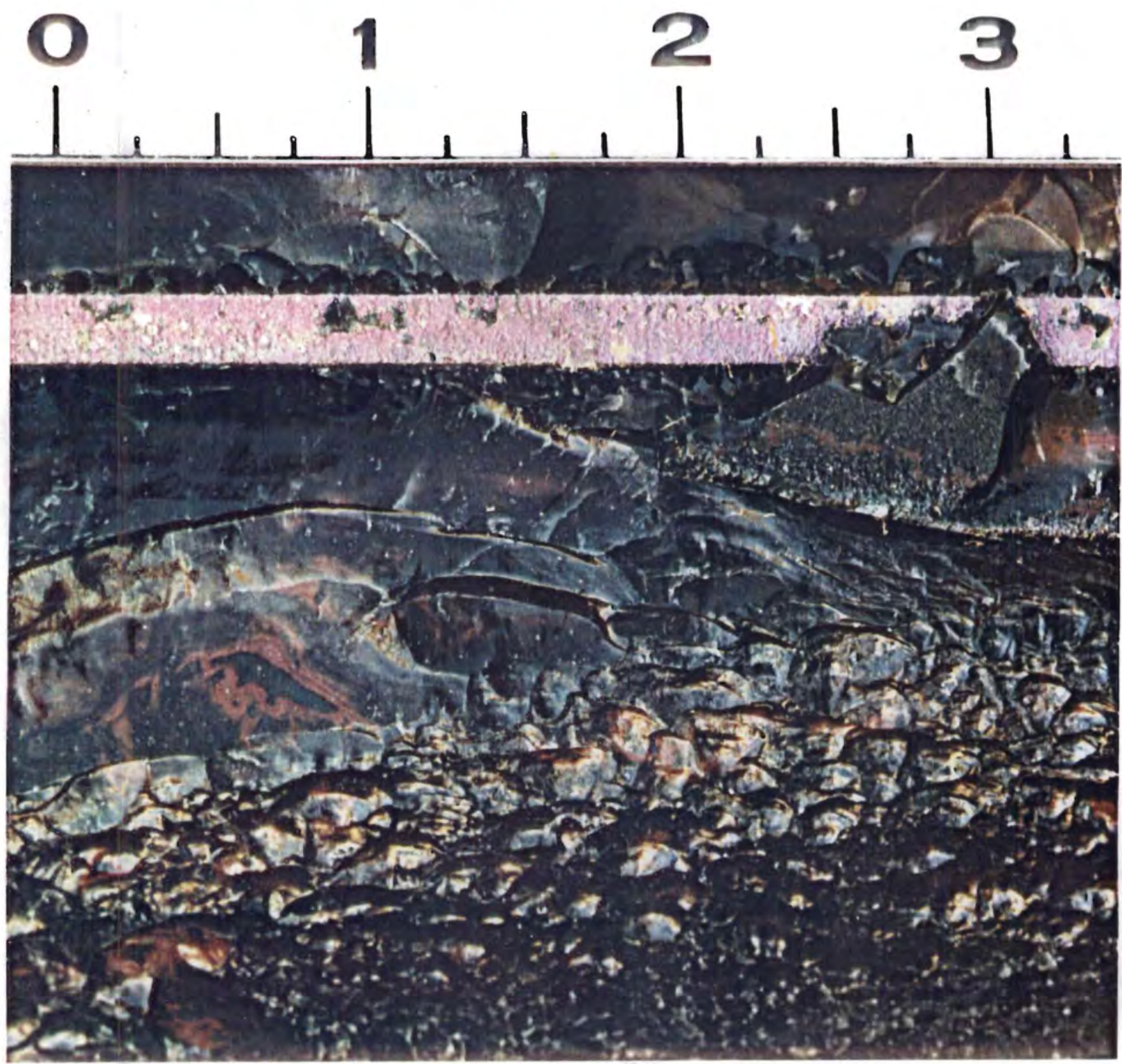

FIGURE 9. Closeup of Fin Corrosion 


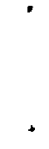




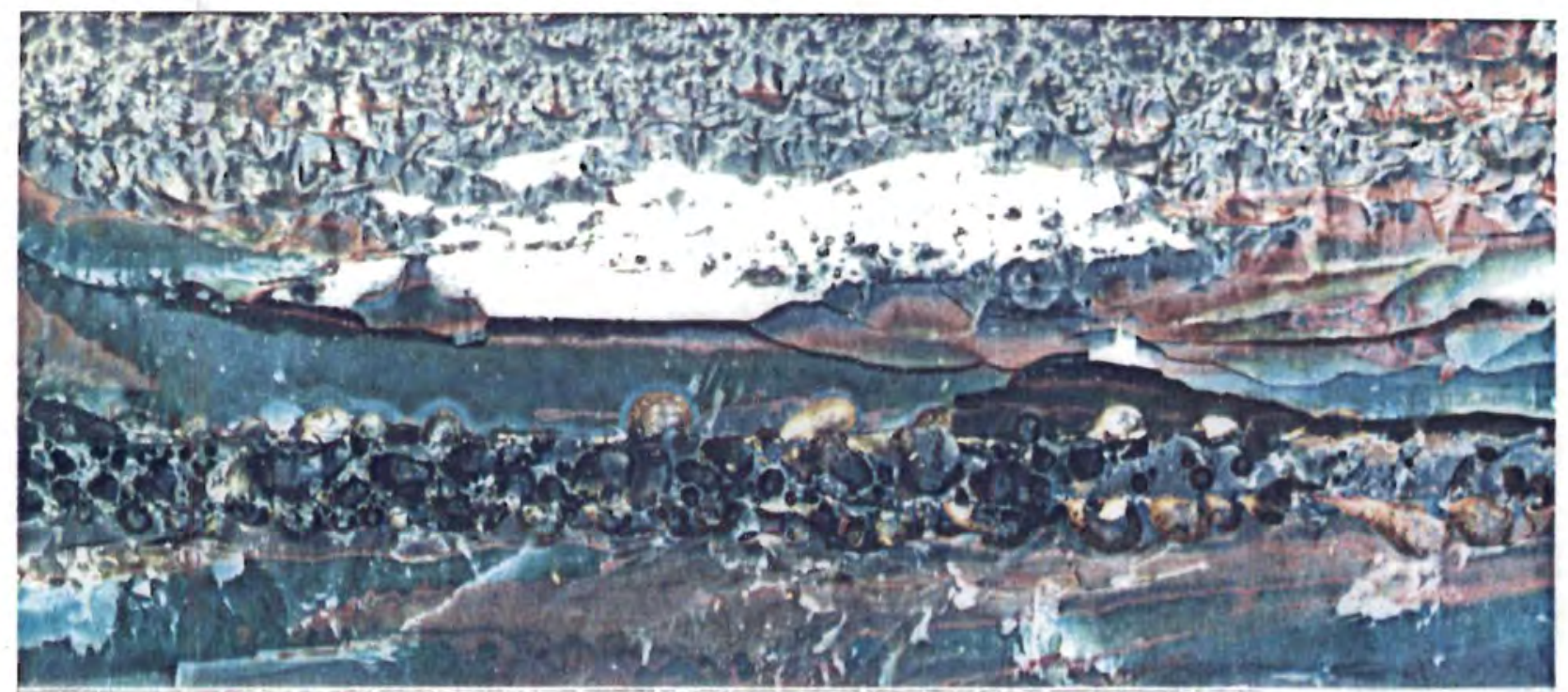
\%

Inches

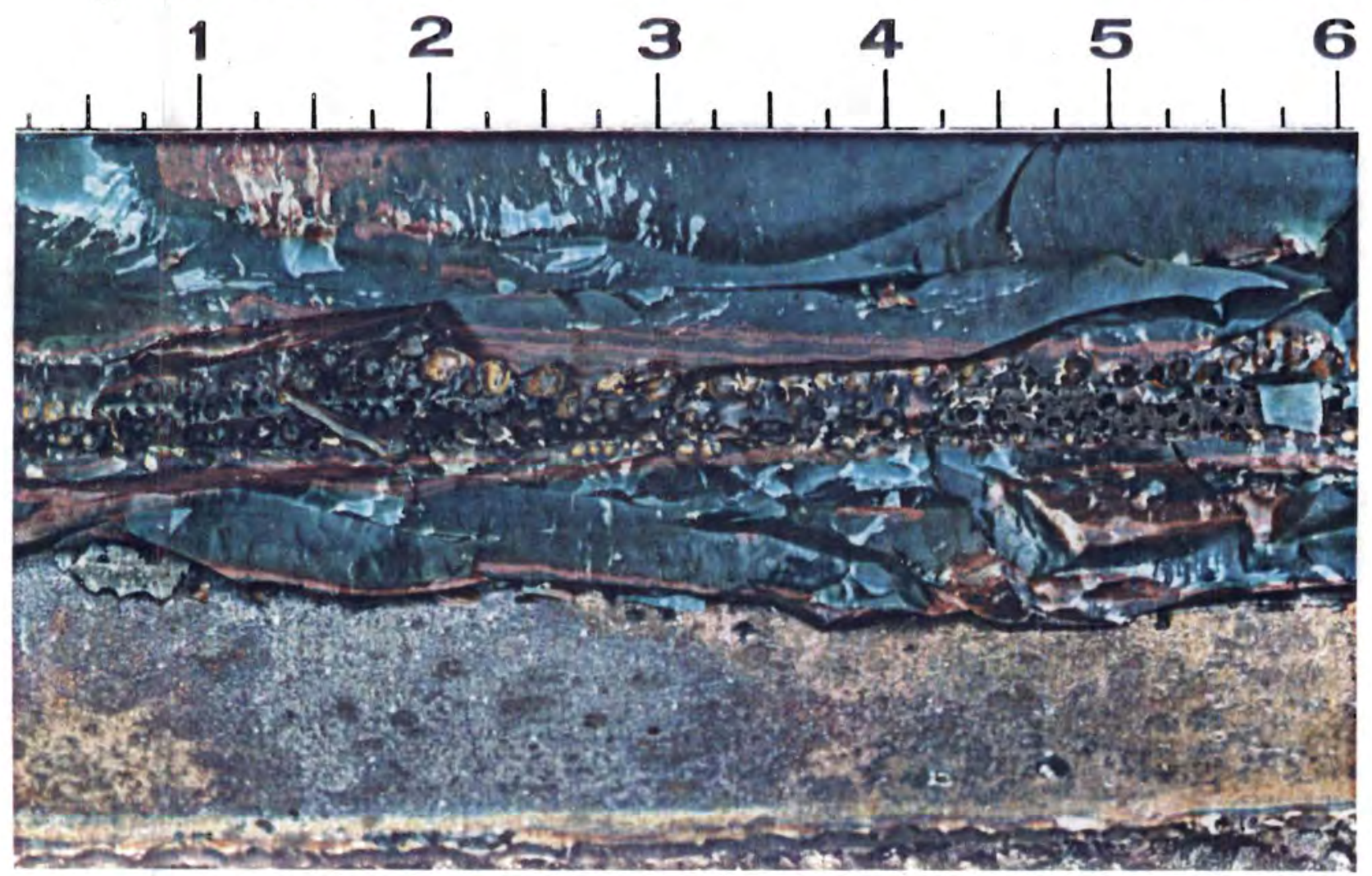

FIGURE 10. ICM-32 Canister Wall Film Corrosion (304L SS) 


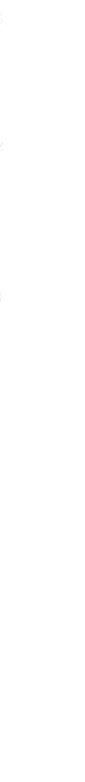




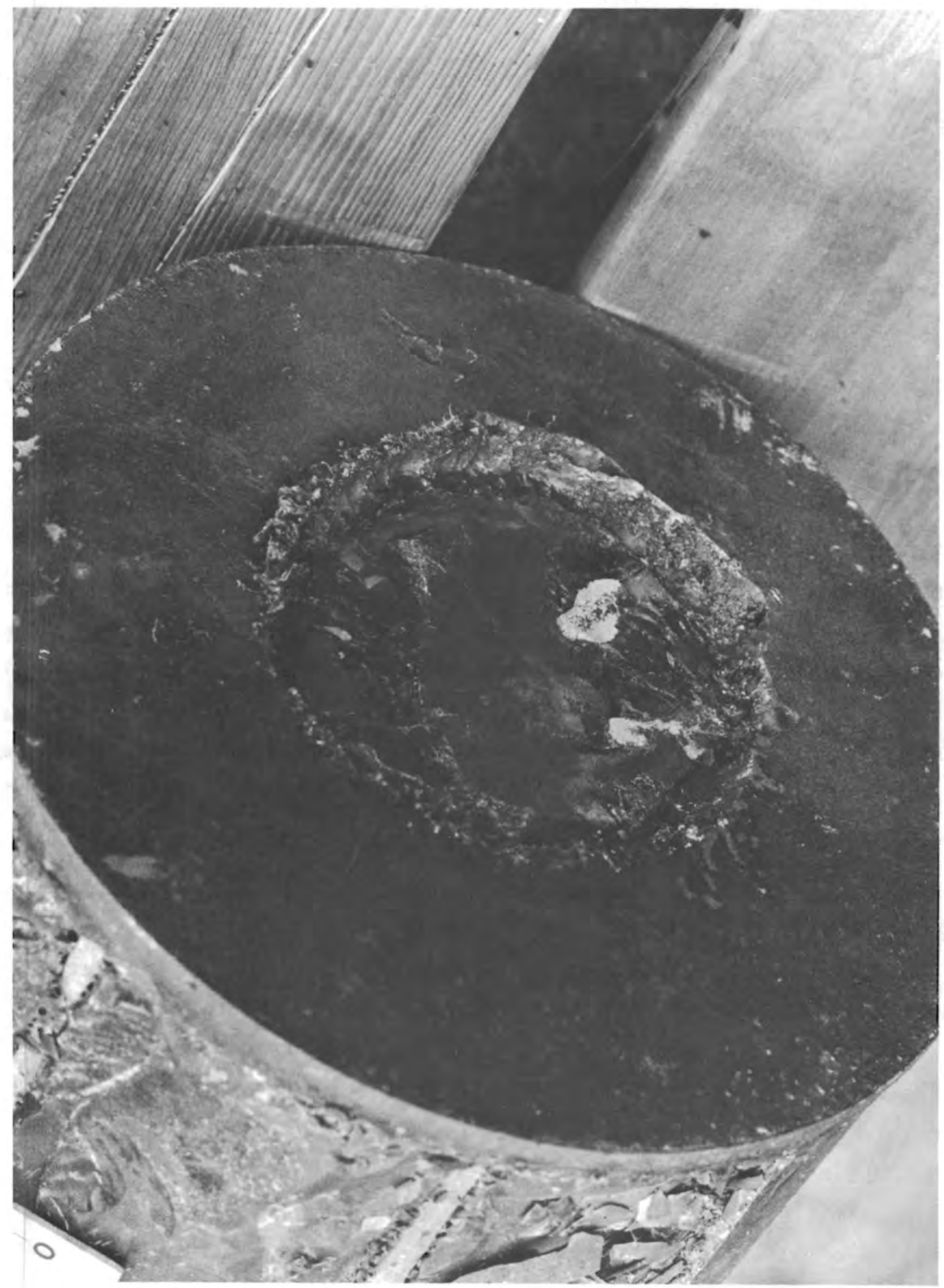

FIGURE 11. Bottom of Canister 
TABLE 2. Venturi Scrubber Solutions Analyses

\begin{tabular}{|c|c|c|c|c|c|c|}
\hline \multirow[b]{2}{*}{ Scrub Solution } & \multirow[b]{2}{*}{ Before Run } & \multicolumn{5}{|c|}{ Time } \\
\hline & & $10: 00$ & $11: 00$ & $12: 00$ & $13: 00$ & $14: 00$ \\
\hline $\mathrm{F}$ & $0.16 \mathrm{~g} / \mathrm{ml}$ & 0.16 & 0.16 & 0.16 & 0.16 & 0.152 \\
\hline Calcium & $20.8 \mathrm{~g} / \mathrm{ml}$ & 21.0 & 20.6 & 20.8 & 20.7 & 20.5 \\
\hline
\end{tabular}

solution. The constant fluoride consentration in the scrub solution indicated that little, if any, volatile fluoride or $\mathrm{CaF}_{2}$ was carried over into the scrub solution.

The corrosion coupons, recovered from the connection section, were examined visually and weighed before and after the run. The coupon located about 20 in. above the canister had a weight gain of $0.47 \mathrm{~g}$. The coupon located about $5 \mathrm{in}$. above the canister also had a weight gain of $0.47 \mathrm{~g}$. The slight weight gains were attributed to oxidation of the coupon surface. The appearance of the coupons did not change during the test, i.e., the sharp corners, edges, and metal shear marks had not been altered. The lower coupon in the connection section was discolored from the heat of the canister but was otherwise unchanged. From these visual observations and the small weight gains, the conclusion was drawn that there was no corrosion problem in the offgas treatment system. In particular, the corrosive coupons showed no evidence of attack by the fluorine.

During the run, a 3-hour caustic bubbler sample was taken. The sampling system is shown in Figure 12. A low flowrate of $1 \mathrm{scfh}$ was chosen to allow small bubble size in the scrubber for adequate gas contact. The scrub solution was $500 \mathrm{ml}$ of $0.5 \mathrm{M} \mathrm{NaOH}$. The scrub solution was analyzed for fluoride ion using an ion chromatograph. The analysis showed an increase of $0.1 \mathrm{~g} / \mathrm{ml}$ fluoride and a decrease of .05 $\mathrm{M} \mathrm{NaOH}$ in the caustic solution above the blank sample taken before the run. Fluoride volatility was determined to be less than $0.0005 \%$ assuming an offgas flow of $5 \mathrm{scfm}$ (actual flow was below the detection limit of the flowmeter), a calcine loading of $33 \mathrm{wt} \%$, a calcine composition of $53 \mathrm{wt} \% \mathrm{CaF}_{2}$, removal by the scrubber of all the fluoride from the gas, and an average feedrate during the sampling period of $18.7 \mathrm{~kg} / \mathrm{h}$. 


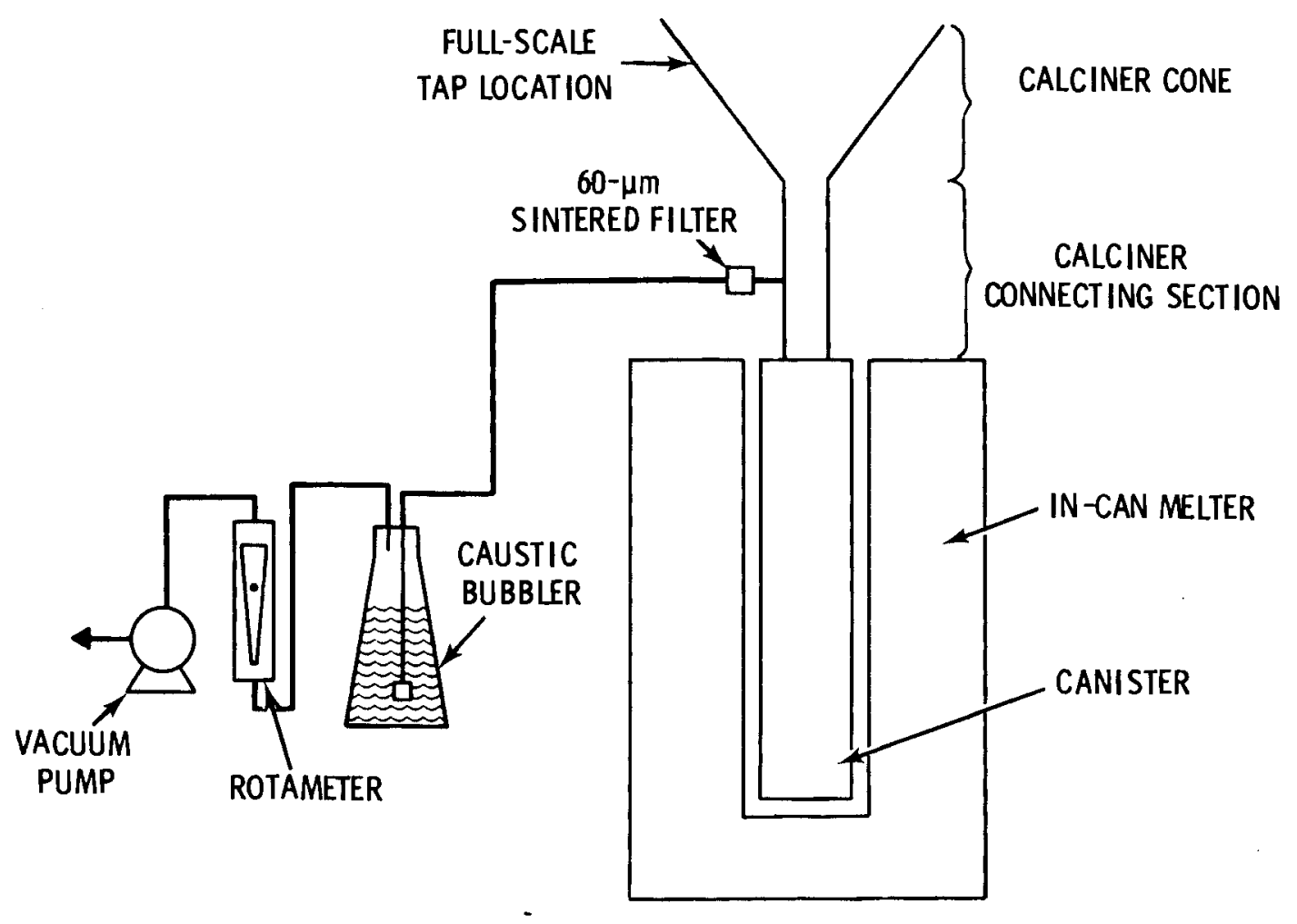

FIGURE 12. Schematic Diagram of Caustic Sampler System 

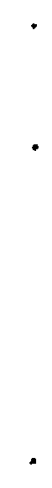

. 


\section{$\underline{\text { FULL-SCALE TEST }}$}

The equipment arrangement for the full-scale test was much the same as it was for the pilot-scale test, i.e., the melter furnace was vented through the spray calciner to the offgas treatment. The offgas train was identical to that used in the pilot-scale test, although it did allow for higher flow rates. Also like the pilot-scale test, the spray calciner was maintained at $200^{\circ} \mathrm{C}$ to keep the sintered metal filters warm, preventing condensation on the filters.

\section{EQUIPMENT}

The full-scale in-can melter is a six-zone resistance-heated furnace. See Figure 13. The furnace is rated at 210 kVA with each zone individually monitored and controlled. The furnace can accommodate a canister size up to $7 \mathrm{ft}$ long and $28 \mathrm{in}$. in dia. The canister is supported on the furnace bottom, and the entire furnace is placed on four load cells to monitor weight gain. The furnace is also equipped with a level-monitoring system, which detects the melt level by attenuation of gama radiation (Blair 1979).

The canister for this test was fabricated from Inconel 601 to avoid the corrosion problems of stainless steel and to observe any differences from the pilot-scale run. The canister was $7 \mathrm{ft}$ long and $24 \mathrm{in}$. in dia with an internal fin assembly of sixteen 304L stainless steel fins. These fins were the only kind we were able to obtain and still meet the project schedule. The canister was fitted with 12 thermocouples (see Figure 14). Two of the thermocouples were spaced radially at the top of the fins to check for bridging; ten thermocouples were located on the canister centerline. Nine of the centerline thermocouples were spaced $8 \mathrm{in}$. apart. The centerline bottom thermocouple was placed 4 in. from the adjacent thermocouple and 4 in. from the canister base.

The connecting section between the canister and the spray calciner/off-gas system has a spout which extends into the furnace. This arrangement allows the canister to be entirely within the heated part of the furnace (see Figure 15). The spout is water-cooled to prevent premature melting and plugging. A water-cooled cone valve located directly on top of the canister shuts off solids flow to the melter during canister change-out. The gravimetric 


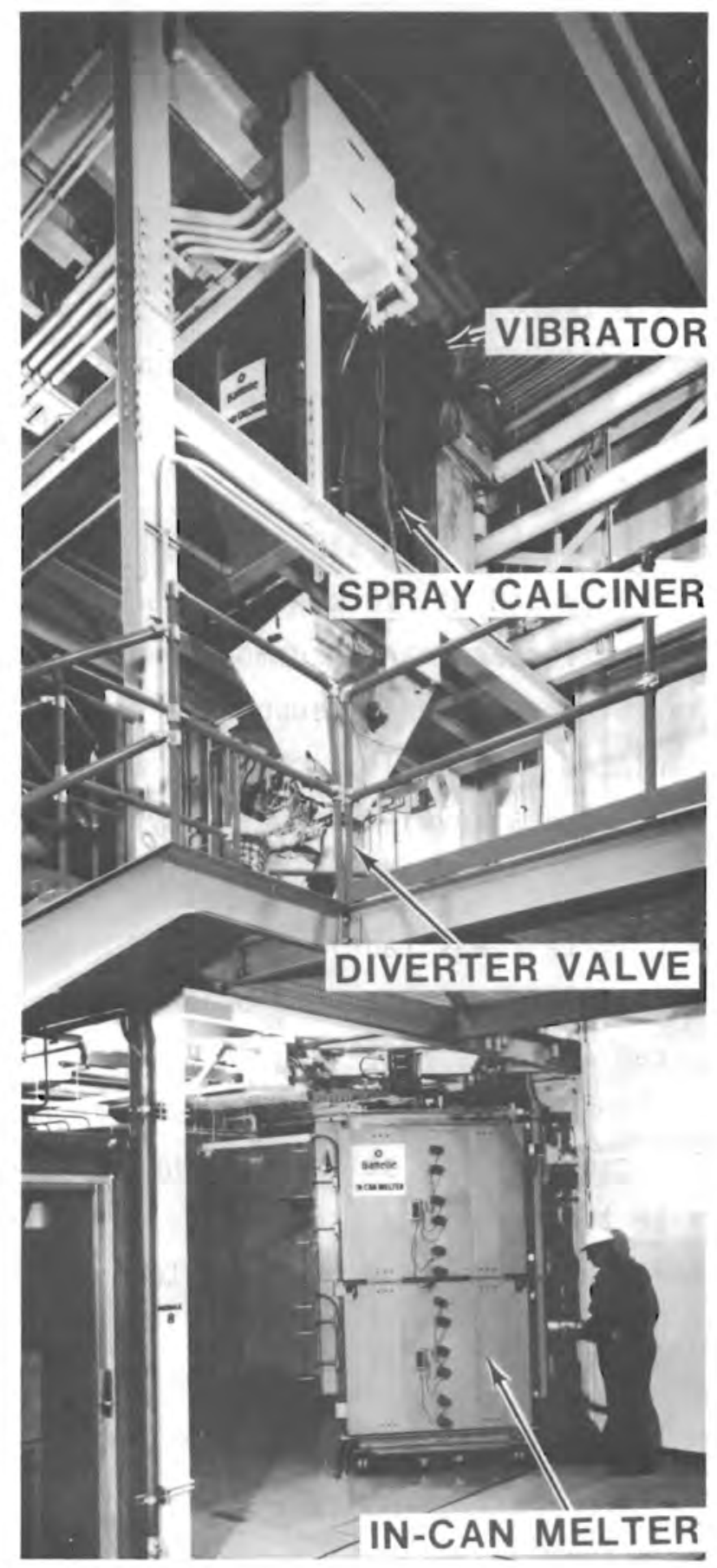

FIGURE 13. Full-Scale Spray Calciner/In-Can Melter 


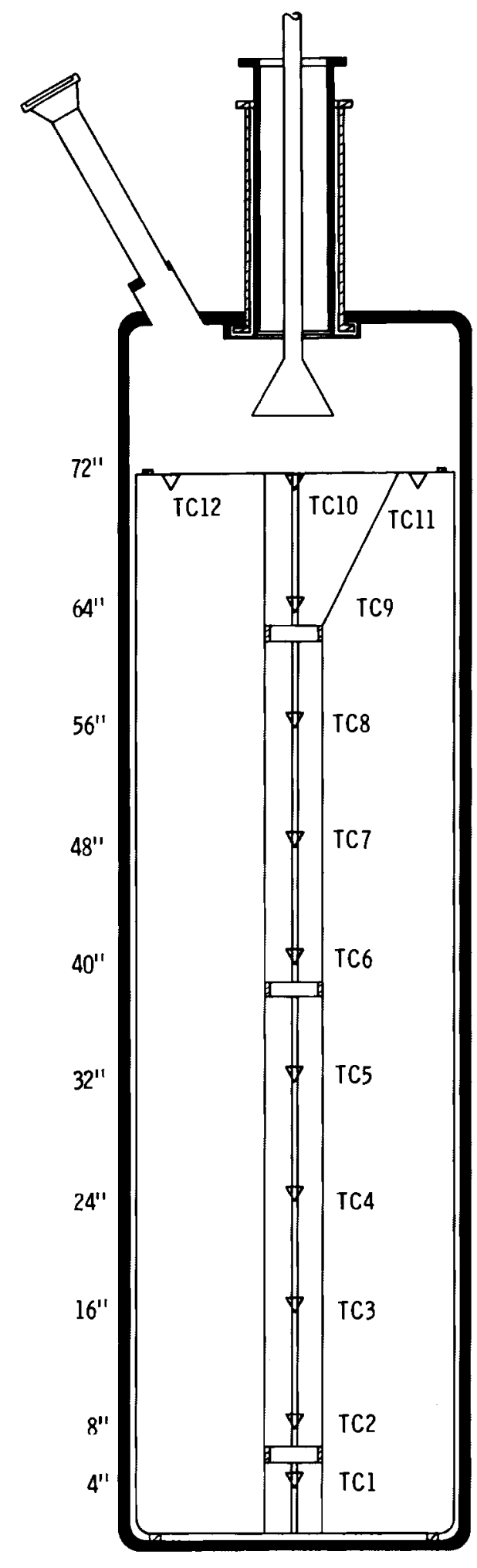

FIGURE 14. Thermocoup le (TC) Placement in Full-Scale Canister 


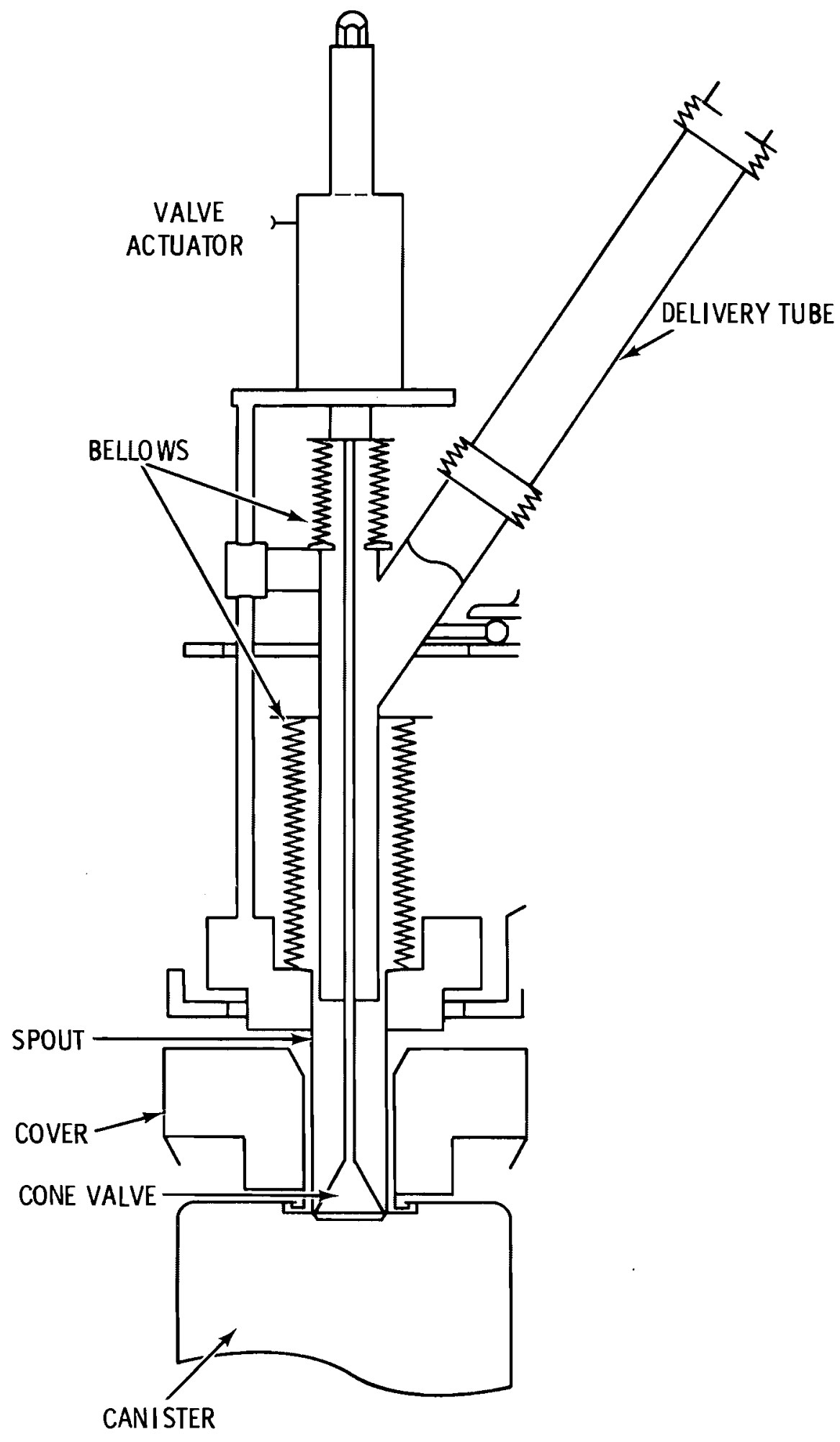

FIGURE 15. Full-Scale In-Can Melter Connecting Section Mechanism 
feeder on the full-scale apparatus is of the identical weighed-belt type as used on the pilot-scale unit. The full-scale unit has a feed capacity of $120 \mathrm{~kg} / \mathrm{h}$.

$\underline{\text { TEST }}$

The in-can melter furnace and canister were heated to $1070^{\circ} \mathrm{C}$ and filling of the canister was begun. The cone valve was inadvertently set to a position in the connecting section which did not allow the feed to pass. The connecting section plugged with the feed and little, if any, of the frit and calcine blend entered the canister. Once the condition was detected, the feed plug was removed and the system was restarted at a feedrate of $60 \mathrm{~kg} / \mathrm{h}$. The feedrate was increased to $80 \mathrm{~kg} / \mathrm{h}$ when it was observed that the furnace handled the initial rate easily. The melter handled the $80-\mathrm{kg} / \mathrm{h}$ peak rate for over $3 \mathrm{~h}$. Overall, it took $32 \mathrm{~h}$ to fill the canister with $1150 \mathrm{~kg}$ of glass. Overall average feedrate was $48 \mathrm{~kg} / \mathrm{h}$. Power consumption was $66 \mathrm{~kW}$ at the peak rate. It takes 35-40 kW of power to hold the furnace at temperature with no feed.

During the run, very little could be seen through an observation port on the canister because of a heavy cloud caused by the calcine fines. At the completion of the run with the feed off, the melt surface could be seen. When the frit and calcine melted at the surface foaming had occurred. The presence of foam, which is a poor heat conductor, may explain the extreme temperature drops which occurred in the top of the full-scale canister and in the pilot-scale canister. The foam's insulating action together with the slight exothermic reaction which occurs in the glass formation, might account for the temperature extremes. This foaming bears further investigating.

During the run; two offgas samples were drawn through the caustic scrubber as done in the pilot-scale test. Pressure above the canister was maintained at approximately -2 in. $\mathrm{H}_{2} \mathrm{O}$. The offgas was routed through the calciner filters, the condenser, and the packed scrubber in the main offgas treatment system.

The canister was filled with feed just below the top of the fins and the glass was melted. After melting all the glass, the canister was again held at 
$1070^{\circ} \mathrm{C}$ for a $1-\mathrm{h}$ soak period. The retraction of the cone valve revealed that the center level of the glass was not even with the sides due to deflection of the feed by the cone valve. Glass shrinkage, due to cooling, had formed a void in the center of the canister. The canister was cooled in the furnace at a rate of $31^{\circ} \mathrm{C} / \mathrm{h}$. When the canister reached near ambient temperatures in the furnace, it was removed. Removal showed a thick coating of calcine on the connecting section (see Figures 16 and 17). This coating was about $1 \mathrm{in}$. thick near the melter and $1 / 2 \mathrm{in}$. thick at the calciner. The coating seemed thinner toward the center of the long straight run between the melter and the calciner. The coating broke away from the connection and fell into the melter during disassembly of the apparatus.

\section{$\underline{\text { TEST RESULTS }}$}

The canister was opened by cutting away a portion of the canister side, exposing the glass and fins. The Inconel canister had none of the surface effects of the stainless steel canister--no corrosion or oxide layer embedded in the glass. The glass properties will be discussed in another section.

Before the coating was knocked off the equipment, the material in the connecting section coating was sampled and analyzed. Two samples were taken--one from the calciner at the top of the connecting section, and one from approximately $30 \mathrm{~cm}$ above the canister at the bottom of the connection. The bottom sample was 1-1/2 in. thick and was composed of two distinct phases, white on the outside, and blue-white on the inside. Each phase was analyzed separately by induction-coupled plasma spectroscopy. The results were compared in the form of a ratio to give the different component amounts. $\mathrm{Ca}, \mathrm{Li}, \mathrm{Na}$ and $\mathrm{Si}$ were found exclusively in the frit and $\mathrm{Al}, \mathrm{Ca}$ and $\mathrm{Zr}$ were found in the calcine. The results of the spectroscopy analysis are compared to the frit and calcine analyses in Table 3. The calculated wt\% frit is based on the $33.7 \%$ silicon analyzed in earlier frit samples. At the top of the connection the wt\% frit was $17 \%$. At the bottom of the connection the wt\% frit was $11 \%$ on the outside and $60 \%$ on the inside. The $60 \%$ frit in the blue-white "inside" sample taken from the bottom of the connection corresponds to the normal feed mixture. 


\section{F.16}

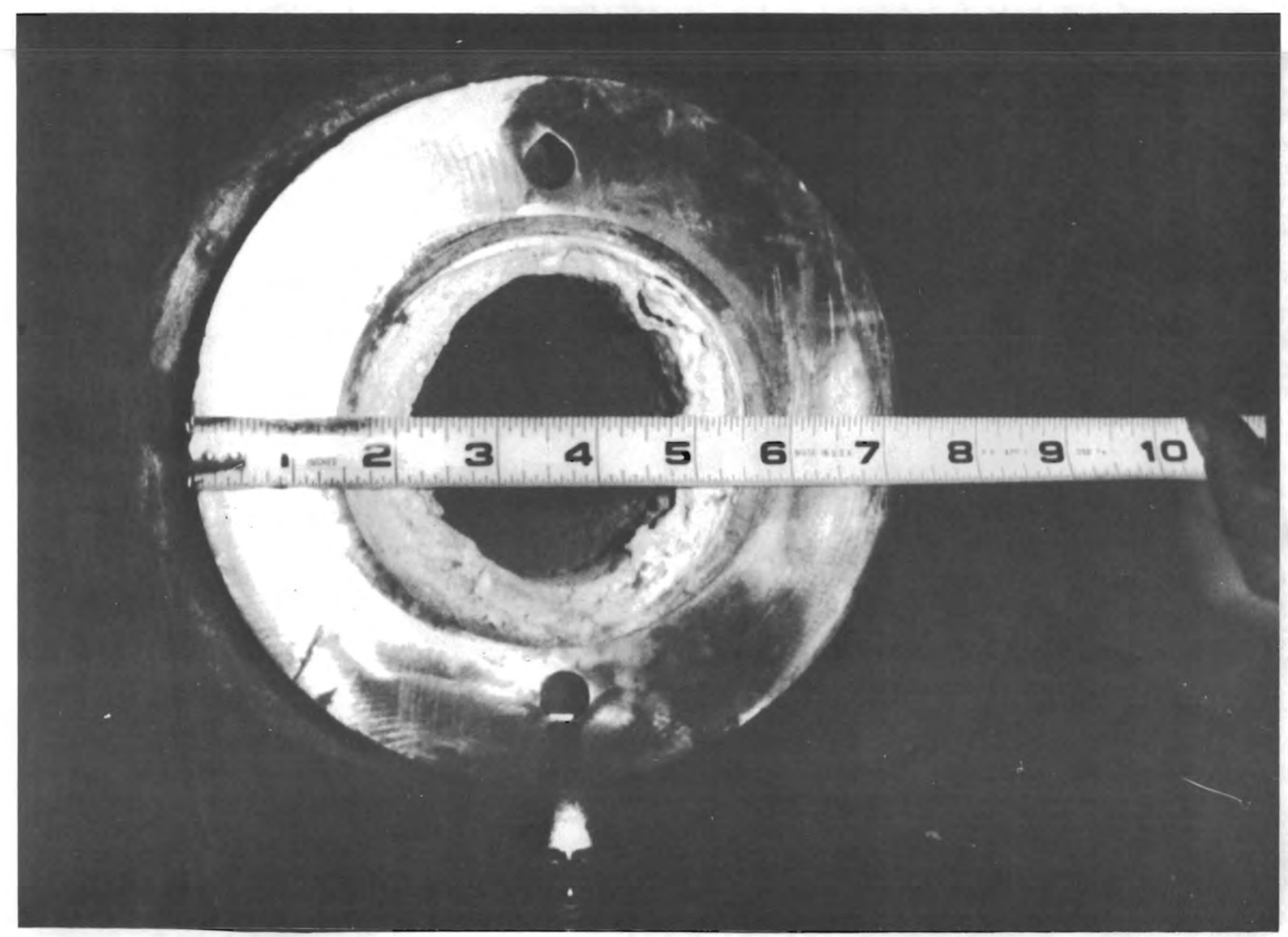

FIGURE 16. Calcine Coating Inside ICM Connecting Section 


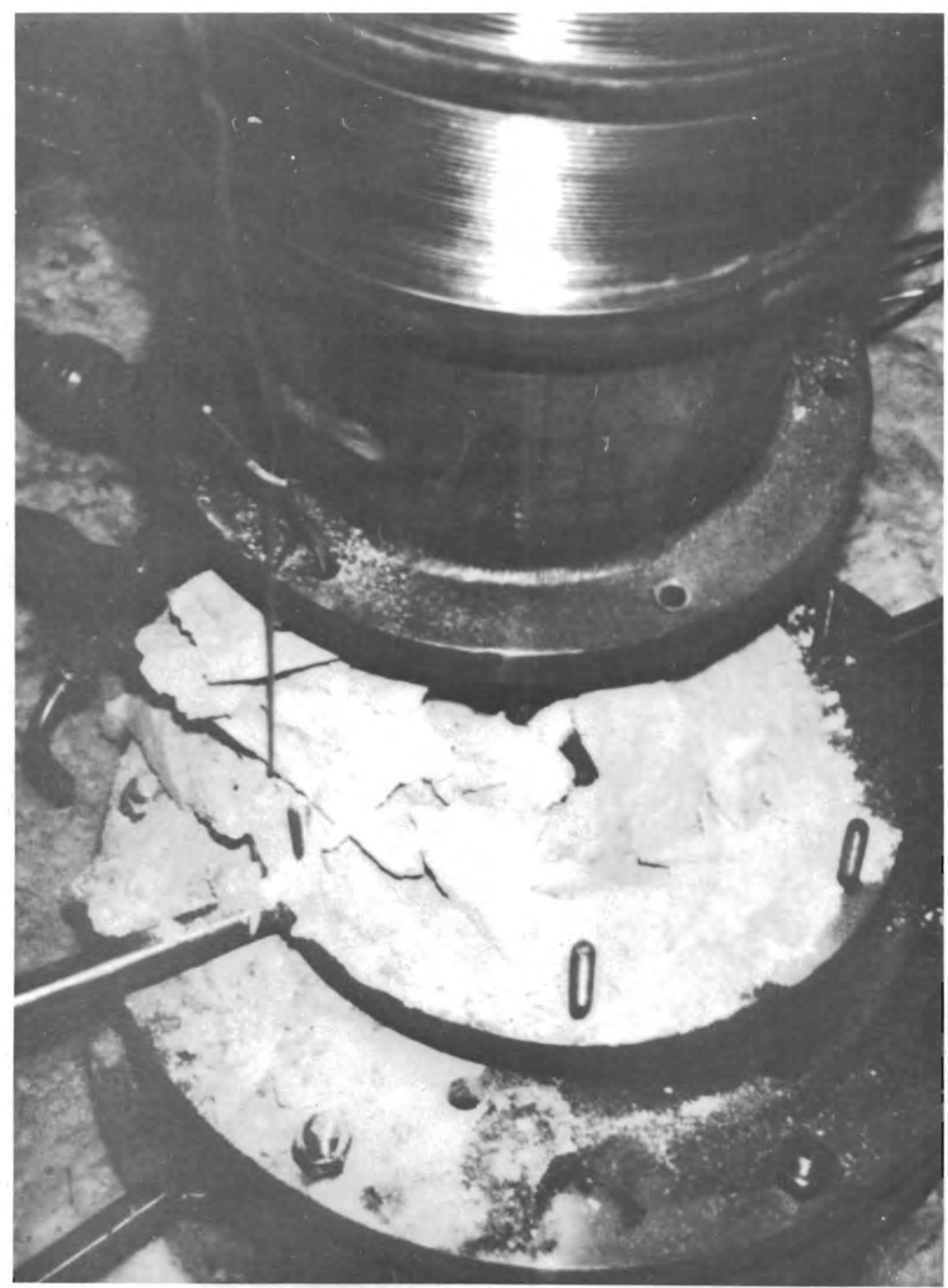

FIGURE 17. Material Accumulated in ICM Connecting Section 
TABLE 3. Analysis by Induction-Coupled Plasma Spectroscopy of Connecting Section Coating

\begin{tabular}{|c|c|c|c|c|c|}
\hline & $\begin{array}{l}\text { Top of } \\
\text { Connection }\end{array}$ & $\frac{\text { Bottom of }}{\text { Outside }}$ & $\frac{\text { Connection }}{\text { Inside }}$ & $\begin{array}{l}\text { Previous } \\
\quad \text { Frit } \\
\end{array}$ & $\begin{array}{l}\text { Previous } \\
\text { Calcine } \\
\end{array}$ \\
\hline $\mathrm{Cu} / \mathrm{Si}$ & 0.039 & 0.038 & 0.046 & 0.052 & --- \\
\hline $\mathrm{Li} / \mathrm{Si}$ & 0.076 & 0.088 & 0.087 & 0.084 & -- \\
\hline $\mathrm{Na} / \mathrm{Si}$ & 0.27 & 0.50 & 0.29 & 0.29 & --- \\
\hline $\mathrm{Al} / \mathrm{Zr}$ & 0.59 & 0.57 & 0.70 & $0--$ & $.36-.42$ \\
\hline $\mathrm{Ca} / \mathrm{Zr}$ & 1.63 & 1.53 & 1.60 & $0--$ & $.81-1.6$ \\
\hline
\end{tabular}

The coating appears to be the result of water condensing at the connecting section that catches the calcine. The calcine then acts as an insulator, warming the area, sending the water vapor higher, and producing a coating that grows up the pipe. The heavier bluish layer may have formed because of the now higher temperatures at the bottom of the connecting section. Sodium compounds will become sticky at elevated temperatures, or the frit itself could get soft and stick to the calcine. The sodium problem occurs at lower temperatures and is more probable. The high sodium content in the bottom outside sample could be from sodium vapor collecting during the early part of the run.

During the run, two caustic samples were taken. The sampling procedure was the same as for the pilot-scale run except the samples were pulled from the spray calciner cone (see Figure 12). Analysis of the scrub solution showed the two samples had the same fluoride concentration as the reference sample taken before the run (about $50 \mathrm{ppb}$ ). Therefore, the fluoride volatility during the full-scale run was essentially zero. 

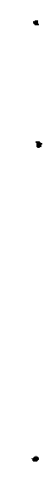

. 


\section{PRODUCT EVALUATION}

Glass from both the pilot-scale canister and full-scale canister was analyzed. A majority of the data is from the pilot-scale canister. Since no compositional changes in the glass were made between pilot and full-scale runs, the basic glass data would be the same for both runs.

\section{COMPOSITION}

Tables 4 and 5 give the chemical compositions of the glass that was characterized before the pilotand full-scale melts and the actual melt products. The composition of the characterized glass was based on a chemical analysis of the calcine used for the run and the desired frit-to-waste ratio, $2: 1$. The composition of the glass produced in the pilot-scale run indicated that the actual ratio was greater than $2: 1$. This greater ratio is probably due to some settling of the calcine in the blending barrel, as only half of this barrel was used in the pilot-scale run. Glass produced in the full-scale run was analyzed and found to be close to the defined composition (see Table 6).

TABLE 4. Chemical Composition Of ICPP ICM-32 Glass

$$
\frac{\text { ICPP-127 (2:1) } \mathrm{Zr} / \mathrm{Calcine}, \text { wt\% }}{\text { In Frit }}
$$

$\begin{array}{lcc}\mathrm{SiO}_{2} & 47.0 & - \\ \mathrm{Na}_{2} \mathrm{O} & 7.3 & - \\ \mathrm{B}_{2} \mathrm{O}_{3} & 5.8 & 1.1 \\ \mathrm{Li}_{2} \mathrm{O} & 5.5 & - \\ \mathrm{CuO} & 1.4 & - \\ \mathrm{Al}_{2} \mathrm{O}_{3} & -- & 5.0 \\ \mathrm{ZrO}_{2} & -- & 9.0 \\ \mathrm{CaF}_{2} & -- & 15.4 \\ \mathrm{CaO}^{2} & -- & 1.0 \\ \text { Other } & -- & 1.5 \\ \text { Total } & -67.0 & 33.0\end{array}$


TABLE 5. Induction-Coupled Plasma (ICP) Analysis of ICPP Waste Glass

$\omega$

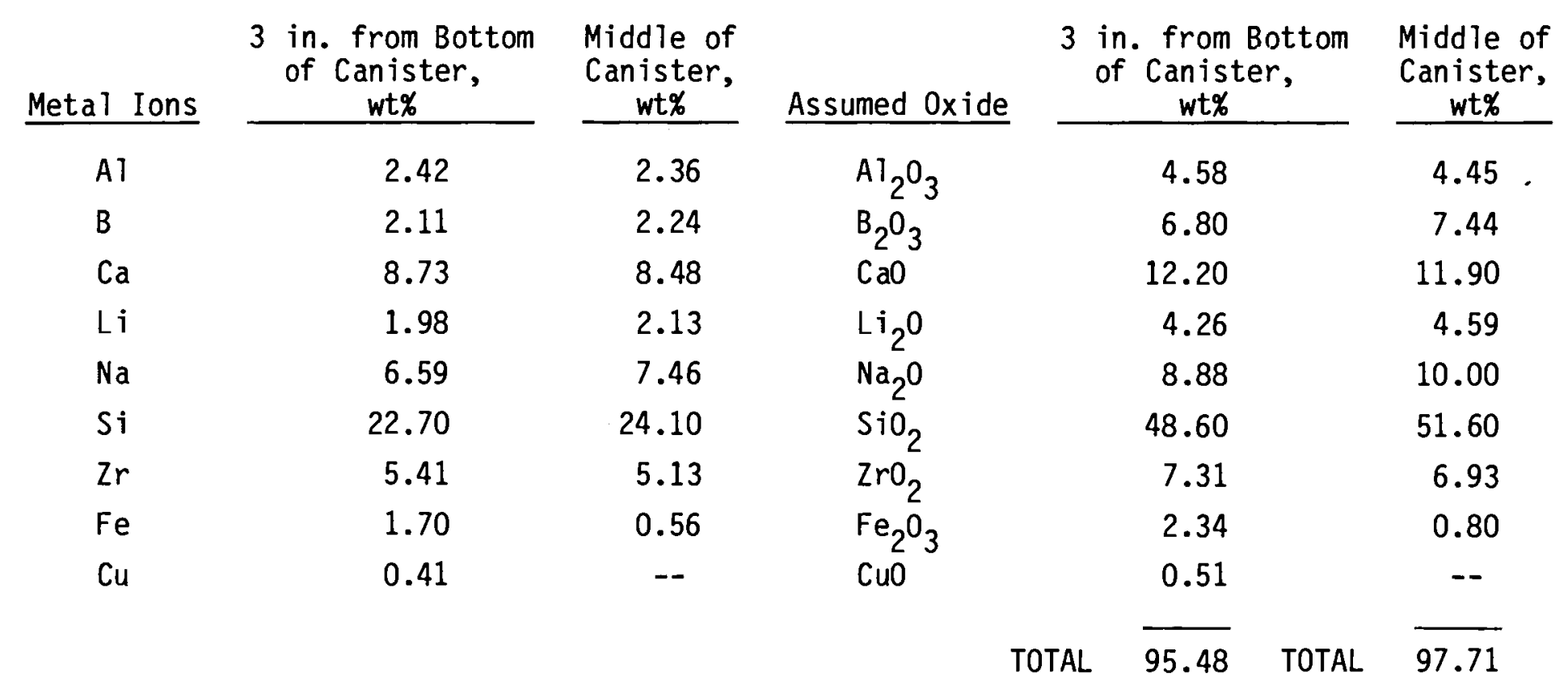


The full-scale run used many complete barrels of feed giving no chance for the component separation that was observed in the pilot-scale run.

The glass in the canister contained areas which varied in color--red, brown, blue, and green. Figure 18 shows the glass made in the pilot-scale equipment. The metal-glass interaction resulted in bubble formation at point A. Brown glass developed at points $B$ and $C$. Pink to red glass at points $D$ and $E$ appeared around the metal surfaces, but no correlation was evident. Transitions occurred from red to green, point $F$, to blue, point $G$, in the glass fragment. Small globules were found at $\mathrm{H}$; these appeared to be metalic, but we were unable to confirm this.

Microprobe measurements were used to analyze areas of each of these colors to determine any difference in composition. The microprobe traces are shown in Figures 19, 20, 21 and 22. No major differences were found between the various areas. The blue glass appears to be slightly enriched with copper

TABLE 6. Full-Scale Canister Inductive-Coupled Plasma (ICP) Analysis

\begin{tabular}{|c|c|c|c|c|c|c|c|}
\hline $\begin{array}{l}\text { Metal } \\
\text { Ions }\end{array}$ & $\begin{array}{l}\text { Top, } \\
\text { wt\% }\end{array}$ & $\begin{array}{c}\text { Middle, } \\
\text { wt\% }\end{array}$ & $\begin{array}{l}\text { Bottom, } \\
\text { wt\% }\end{array}$ & $\begin{array}{l}\text { Assumed } \\
\text { Oxide } \\
\end{array}$ & $\begin{array}{l}\text { Top, } \\
w t \% \\
\end{array}$ & $\begin{array}{c}\text { Middle, } \\
\text { wt\% }\end{array}$ & $\begin{array}{c}\text { Bottom, } \\
\text { wt\% }\end{array}$ \\
\hline Al & 2.29 & 2.46 & 2.69 & $\mathrm{Al}_{2} \mathrm{O}_{3}$ & 4.33 & 4.65 & 5.08 \\
\hline B & 1.98 & 2.13 & 2.10 & $\mathrm{~B}_{2} \mathrm{O}_{3}$ & 6.38 & 6.86 & 6.76 \\
\hline $\mathrm{Ca}$ & 7.63 & 8.55 & 8.96 & $\mathrm{CaO}$ & 10.7 & 12.0 & 12.5 \\
\hline $\mathrm{Cu}$ & 0.88 & 0.92 & 0.72 & CuO & 1.10 & 1.15 & 0.90 \\
\hline Li & 1.85 & 1.90 & 1.93 & $\mathrm{Li}_{2} \mathrm{O}$ & 3.98 & 4.09 & 4.15 \\
\hline $\mathrm{Na}$ & 5.74 & 6.58 & 5.96 & $\mathrm{Na}_{2} \mathrm{O}$ & 7.74 & 8.87 & 8.03 \\
\hline Si & 20.70 & 22.30 & 21.3 & $\mathrm{SiO}_{2}$ & 44.3 & 47.7 & 45.6 \\
\hline$Z r$ & 4.50 & 4.93 & 5.14 & $\mathrm{ZrO}_{2}$ & 6.08 & 6.66 & 6.94 \\
\hline $\mathrm{Cr}$ & 0.27 & 0.30 & 0.36 & $\mathrm{Cr}_{2} \mathrm{O}_{3}$ & 0.39 & 0.44 & 0.53 \\
\hline \multirow[t]{3}{*}{$\mathrm{Fe}$} & 0.83 & 0.90 & 1.96 & $\mathrm{Fe}_{2} \mathrm{O}_{3}$ & 1.19 & 1.29 & 2.80 \\
\hline & & & & TOTAL & 86.20 & 93.70 & 93.30 \\
\hline & & & & $\operatorname{TOTAL}^{(a)}$ & 90.1 & 98.0 & 97.9 \\
\hline
\end{tabular}

(a) Assuming No $\mathrm{F}^{-}$loss $\left(\mathrm{Ca}^{++} \times 1.909\right)$ minus $\mathrm{CaO}$ wt\%: $\mathrm{Caf}_{2}+\mathrm{CaO}$ in calcine using $3 \% \mathrm{CaO}$ (from frit) and $53 \% \mathrm{CaF}_{2}$ (from feed). 


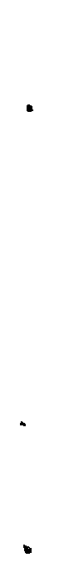



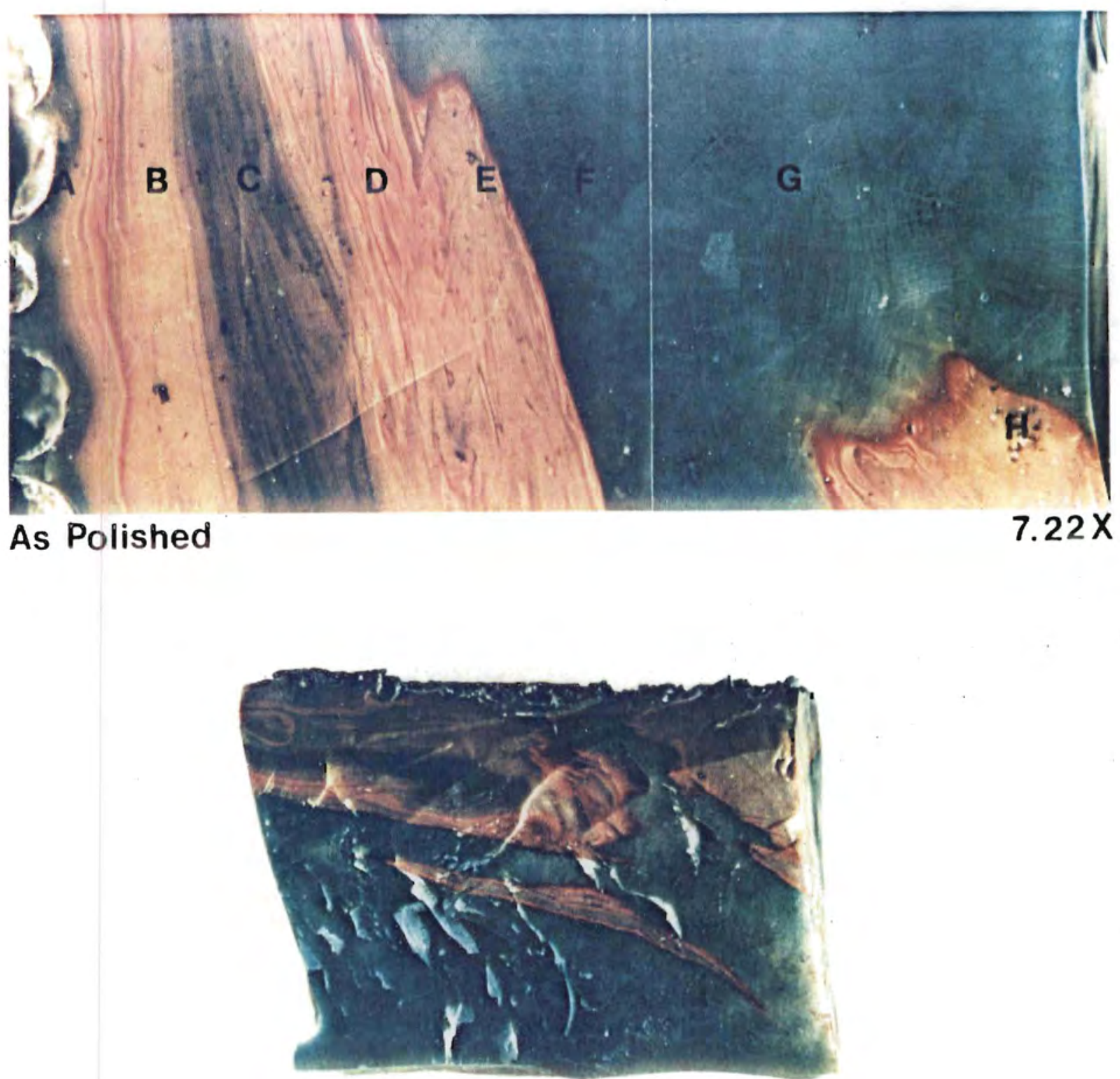

As Received $\quad 2.09 \mathrm{X}$

FIGURE 18. Micrograph ICM - 32 Glass 


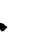




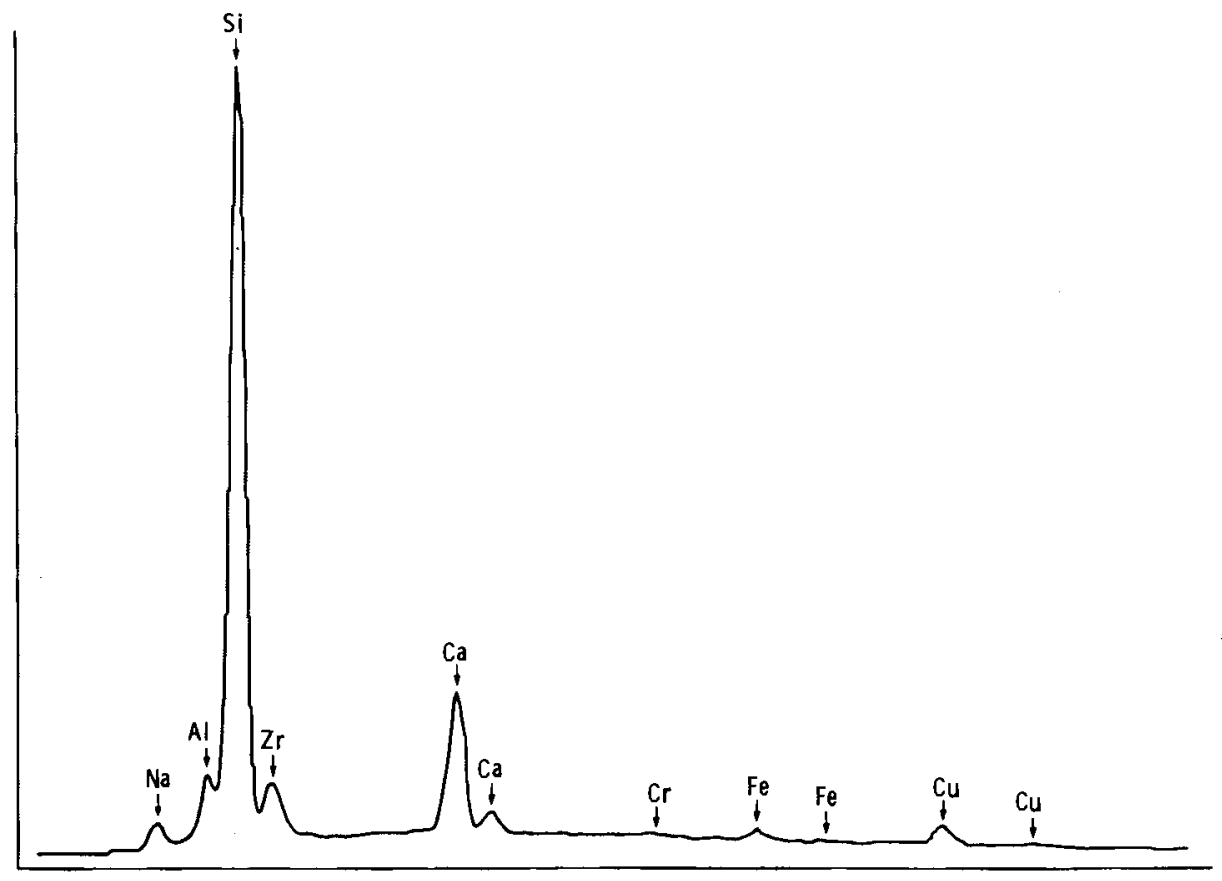

FIGURE 19. Microprobe Trace for Blue Glass

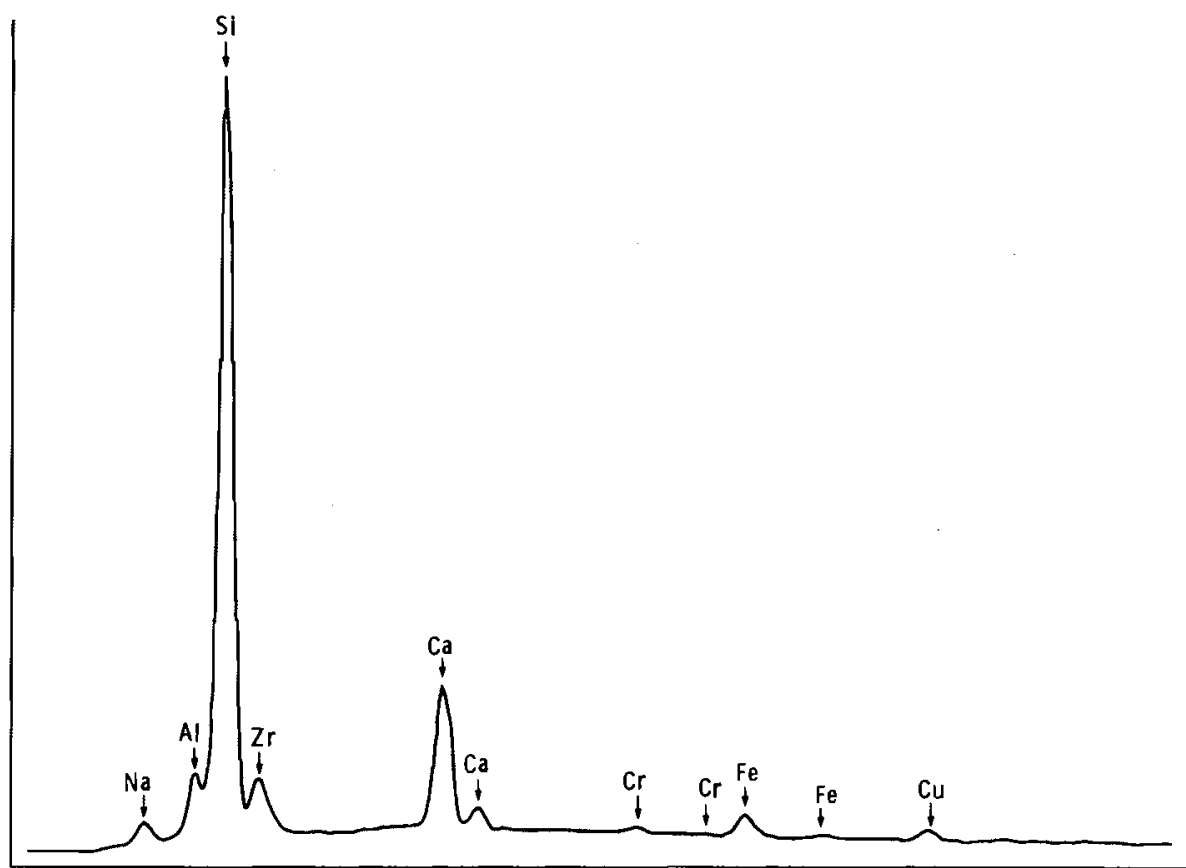

FIGURE 20. Microprobe Trace for Green Glass 


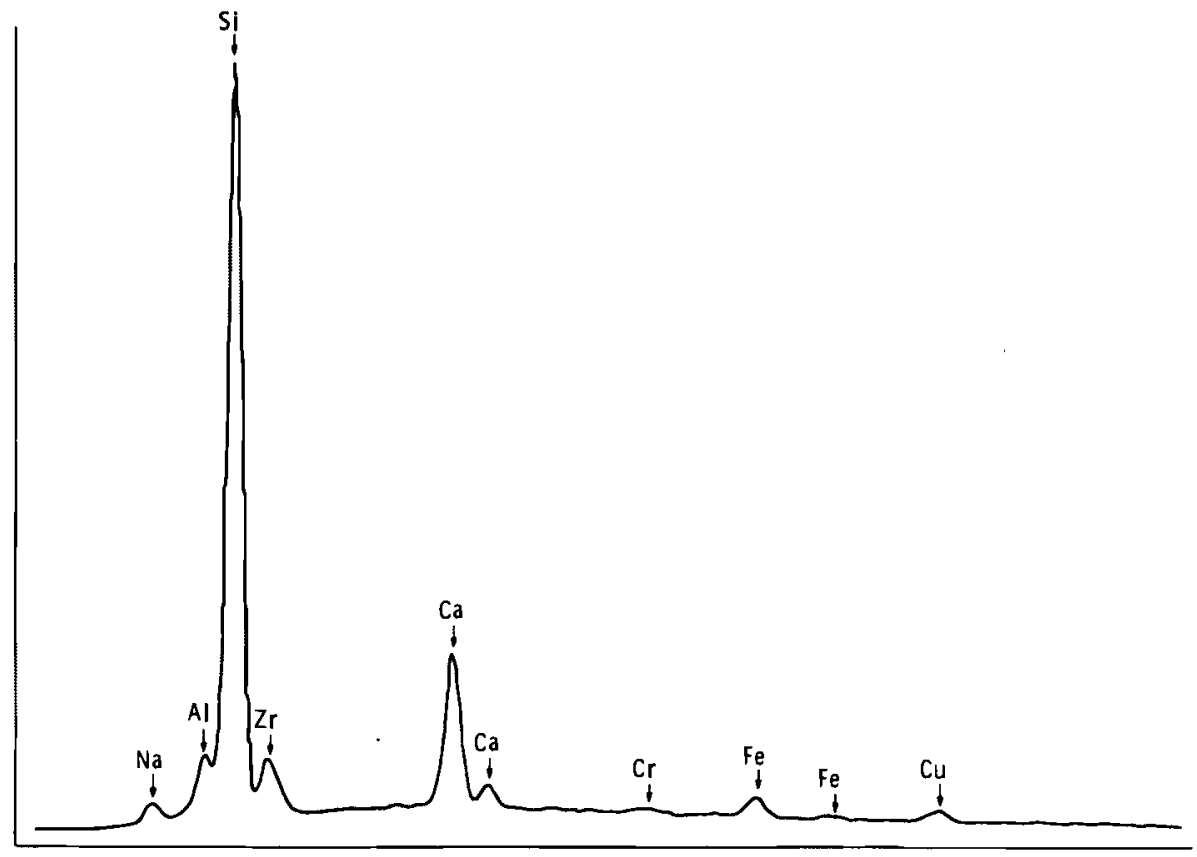

FIGURE 21. Microprobe Trace for Red Glass

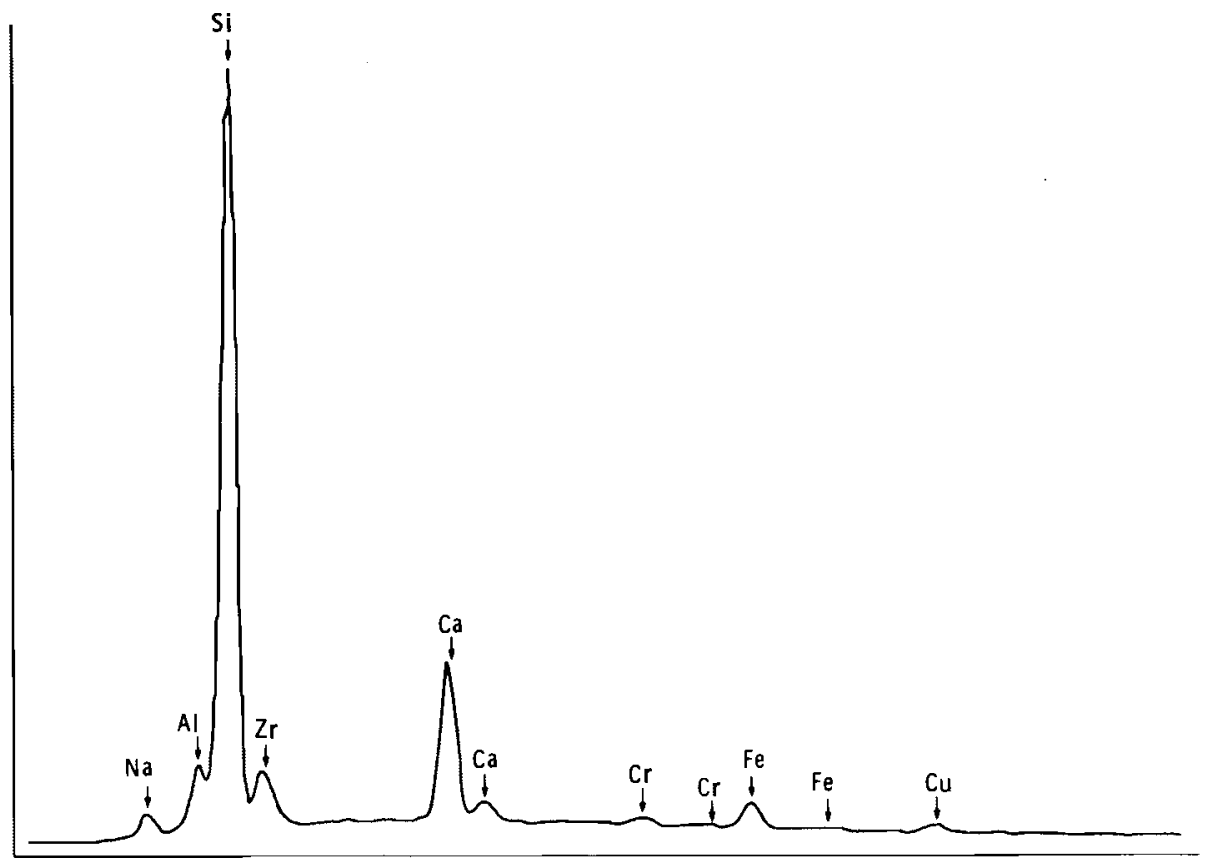

FIGURE 22. Microprobe Trace for Brown Glass 
and depleted in iron. The brown glass is slightly enriched with iron and depleted in copper. The iron probably resulted from corrosion of the stainless steel canister.

Major chemical differences do not exist, indicating that the colors are probably due to a difference in oxidation state of one or more of the multivalent metallic species in the glass. The red coloring occurred close to fins and canister walls, a more reducing environmemt than the body of the glass. A similar red-green color variation was previously found in other glasses containing copper and reducing agents. Iron probably did not contribute to the coloration difference as was speculated after seeing some corrosion on the stainless steel pilot canister. The color variation was found then this glass was melted in platinum crucibles where no iron contamination could have occurred.

\section{DENSITY}

Densities of the glass samples were tested by measuring the amount of mercury displaced by the sample at atmospheric pressure. The glass samples were taken 9 in., 18 in., 27 in., and 36 in. from the bottom of the pilot-scale canister. The density of each sample was relatively constant, ranging from 2.70 to $2.73 \mathrm{~g} / \mathrm{cm}^{3}$. The sample taken 9 in. from the bottom of the canister was more dense than the sample taken $36 \mathrm{in}$. from the bottom, which would be expected. Results of the density measurements are shown in Table 7.

\section{TABLE 7. Chemical and Physical Properties of ICPP Waste Glass} in Pilot-Scale Canister

\begin{tabular}{|c|c|c|c|c|c|c|}
\hline \multirow[b]{2}{*}{$\begin{array}{l}\text { Sample Distance } \\
\text { From End of } \\
\text { Canister, in. }\end{array}$} & \multicolumn{4}{|c|}{ Chemical Properties } & \multicolumn{2}{|c|}{ Physical Properties } \\
\hline & $\begin{array}{c}72-h \\
\text { Soxhlet Test } \\
\text { wt\% }\end{array}$ & $\begin{array}{l}\text { Leach Rate, } \\
g / c c^{2} / \text { day }\end{array}$ & $\begin{array}{l}\text { 19-h } \\
\text { Acid Leach Test } \\
(\mathrm{pH} 4) \text {, wt\% (b) }\end{array}$ & $\begin{array}{l}\text { Base Leach Test } \\
(\mathrm{pH} 9) \text {, wt\% }\end{array}$ & $\begin{array}{l}\text { Density } \\
g / c c^{3} \\
\end{array}$ & Porosity, $\%$ \\
\hline 9 & 1.63 & $2.09 \times 10^{-5}$ & 0 & 0 & 2.73 & 0.08 \\
\hline 18 & 1.77 & $2.26 \times 10^{-5}$ & 0 & 0 & 2.70 & 0.0 \\
\hline 27 & 1.58 & $2.02 \times 10^{-5}$ & 0 & 0 & 2.71 & 0.13 \\
\hline 36 & 1.86 & $2.38 \times 10^{-5}$ & 0 & 0 & 2,70 & 0.09 \\
\hline
\end{tabular}

(a) At $99^{\circ} \mathrm{C}$ Distilled $\mathrm{H}_{2} \mathrm{O}$.

(b) Weight losses, if any, were too small to be detected. 
POROSITY

Tests were conducted to determine the porosity of the glass samples taken 9 in., 18 in., 27 in., and 36 in. from the bottom of the pilot-scale canister. The porosity was determined by measuring the amount of mercury that penetrated each sample through pores in the glass when pressures up to 5000 psig were applied to the mercury. The percent porosity of these samples was quite low, ranging from $0.08 \%$ to $0.13 \%$. See Table 7 . The sample taken 18 in. from the bottom of the canister did not show any porosity. A small portion of glass near the canister wall showed some obvious pores.

\section{LEACH TESTING}

ICM product samples, cored from various locations in the cansiter, were measured for chemical durability. The pilot-scale samples' leaching qualities were determined through the soxhlet leaching method and by leaching the samples at $\mathrm{pH} 4$ and $\mathrm{pH} 9$ (see Table 7). The full-scale samples were analyzed by the soxhlet method only; the results are presented in Table 8 . Very little variation in durability was found in the samples. An indicator of good product durability is the extremely low weight losses of the samples, due in part to the high $\mathrm{SiO}_{2}$ content (about 52 wt\%) and the high $\mathrm{ZrO}_{2}$ content (about 7 wt\%). The source for the $\mathrm{ZrO}_{2}$ was the calcine. The uniformity of the leach results indicates that there probably were no major variations in frit-to-calcine ratios within the canister. Because the leach rate was affected by the amount of $\mathrm{ZrO}_{2}$ in the glass, changes in the frit-to-calcine ratio would have a great effect on chemical durability.

Samples taken from the full-scale canister compare favorably in durability to the pilot-scale samples. Of particular interest was the relatively low

\section{TABLE 8. Full-Scale Canister Leach Data}

Sample Location

Slag Layer - Top of Canister

Upper $1 / 3$ of Canister

Middle of Canister

Lower $1 / 3$ of Canister
Soxhlet Distilled $\mathrm{H}_{2} 0$ Loss after $72 \mathrm{~h}$, wt\%

4.35

1.90

1.67

1.59 
leach rate of the slag layer that accumulated on top of the canister. The weight loss of this layer was only about 2.5 times greater than the weight loss of the other glass samples. While this unfixed layer of material on top of the glass has elicited concern in the in-can melting process, it should be noted that the material on top of the ICPP glass was not significantly higher in leach rate than the bulk of the glass. Specific analysis of this slag material was not performed.

\section{CRYSTALLINITY}

The crystallinity content of both the green and brown glass phases present in the pilot-scale canister was determined using X-Ray diffraction. The brown glass phase contained $8.0 \% \mathrm{CaF}_{2}$ crystals referred to as the mineral dendrite. The green glass phase contained $9.4 \% \mathrm{CaF}_{2}$ which is a constituent of the calcine. Glass made in the laboratory showed crystallinity of $30 \%$ to $35 \%$. Maintaining the correct frit-to-calcine ratio is an important processing consideration of this ICPP glass from the standpoint of crystal content because excess calcine will result in the precipitation of $\mathrm{CaF}_{2}$. Cooling rates and the oxidation states and cooling rates of the glass may also have an effect on the crystallinity. 
. 


\section{CONCLUSIONS AND RECOMMENDATIONS}

Based on data obtained thus far, the ICPP waste glass appears to be a promising canidate for immobilization. The glass showed low leach-rate results. Analys is of different glass samples indicated they were chemically homogeneous; although color variations of red, brown, blue, and green implied some changes taking place in the canister. Viscosity and conductivity were low, making the glass conducive to electric melting. The calcine and frit blend was free flowing and easily handled, although dusting was a problem.

The few processing problems that were encountered can be minimized through proper processing conditions. The glass had a dull appearance due to a significant amount of crystallinity. The major crystalline phase was identified as dendrite. The formation of calcine cakes on the melter components indicated that further study should be conducted on the performance of the the in-can melter. The corrosiveness of the glass was unquestioned, and although fluorine was not an offgas problem, confirmation should be established.

Minimal experiments were conducted to profile waste-glass characteristics. Further study is recommended for the following:

1. The 304L stainless steel canisters containing waste glass corroded visibly, but corrosion did not appear to affect the waste glass. Canister materials and design may be affected by corrosion in long-term storage.

2. Offgas data showed no fluoride migration out of the canister. Longer tests would be needed to confirm this observation.

3. The waste glass did not show any signs of we ight loss in $\mathrm{pH} 4$ and $\mathrm{pH} 9$ solutions. Hydrothermal tests would assist the determination of product durability.

4. Because thermal conductivity is an important property in glass, further measurements of the conductivity are advisable.

5. The calcine had a tendency to coat the connecting offgas lines. This tendency probably is due to water vapor, but the problem should be investigated and resolved. 
6. The area around the glass/unmelted frit and calcine interface tended to be cooler during both runs. This behavior was contrary to earlier data and could affect processing parameters and glass quality.

7. Apparently nonhomogeneities in the glass are due to changing oxidation conditions. The sensitivity of the glass to such oxidation problems should be evaluated.

8. Effects of process temperatures, glass cooldown, and glass composition on product crystallinity need to be determined.

9. The ICPP glass composition behaved well in the ICM tests. This composition may be applied also to other immobilization technologies (e.g., ceramic melters), but refractory corrosion studies should be undertaken first. 


\section{REFERENCES}

Blair, H. T. 1979. In-Can Melting Process and Equipment Development From 1974 to 1978. PNL-2925, Pacific Northwest Laboratory, Richland Washington.

Gombert, D. 1979. Vitrification of High-Level 1CPP Calcined Wastes. 1CP1177, Allied Chemical Corp., Idaho Falls, Idaho. 


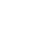




\section{DISTRIBUTION}

No. of

Copies

OFFSITE

A. A. Churm

DOE Chicago Patent Divsion 9800 South Cass Avenue

Argonne, IL 60439

R. E. Cunningham

Deputy Director for Fuels and Materials

Nuclear Regulatory Commission

Silver Springs, MD 20910

K. A. Carlson

DOE Office of Nuclear Waste Management

Washington, DC 20545

T. C. Chee

DOE Office of Nuclear Waste Management

Washington, DC 20545

C. R. Cooley

DOE Office of Nuclear Waste Management

Washington, DC 230545

Sheldon Meyers

DOE Office of Nuclear Waste Management

Washington, DC 20545

R. G. Romatowski

DOE Office of Nuclear Waste Management

Washington, DC 20545

D. M. Rohrer

United States Nuclear Regulatory Commission

Washington, DC 20555
No. of

Copies

C. A. Heath

DOE Office of Nuclear Waste Management

Washington, DC 20545

G. 0ertel

DOE Office of Nuclear Waste Management

Washington, DC 20545

A. F. Perge

DOE Office of Nuclear Waste

Management

Washington, DC 20545

R. D. Walton

DOE Office of Nuclear Waste Management

Washington, DC 20545

W. E. Mott

DOE Division of Environmental

Control Technology

Washington, DC 20545

J. Neff, Program Manager

Department of Energy

Columbus Program Office

505 King Avenue

Columbus, $\mathrm{OH} 43201$

John Van Cleve

DOE Oak Ridge Operations office P. 0 . Box $X$

Oak Ridge, TN 37830

J. B. Whitsett

DOE I daho Operations Office

P. 0. Box 2108

Idaho Falls, ID 83401 
No. of

Copies

E. S. Goldberg

DOE Savannah River Operations Office

P. 0. Box A

Aiken, SC 29801

27 DOE Technical Information Center

J. R. Berreth

Exxon Nuclear Idaho Cirp.

Box 2800

Idaho Falls, ID 83401

R. A. Brown

Exxon Nuclear Idaho Corp

Box 2800

Idaho Falls, ID 83401

J. D. Christian

Exxon Nuclear Idaho Corp.

Box 2800

Idaho Falls, ID 83401

Exxon Nuclear Idaho Corfp.

(File Copy)

Box 2800

Idaho Falls, ID 83401

A. Williams

Allied-General Nuclear Service P. 0. Box 847

Barnwe 11, SC 29812

J. L. Jardine

Argonne National Laboratory

9700 South Cass Avenue

Argonne, IL 60439

M. M. Steindler/L. E. Trevorrow Argonne National Laboratory

9700 South cass Avenue

Argonne, IL 60439

Wayne Carbiener

Battelle Memorial Institute

505 King Ave.

Columbus, $\mathrm{OH} 43201$
No of

Copies

J. Kircher

Office of Nuclear Waste Isolation

Battelle Memorial Institute 505 King Ave.

Columbus, $\mathrm{OH} 43201$

Beverly Rawles

Office of Nuclear Waste Isolation

Battelle Memorial Institute

505 King Ave.

Columbus, $\mathrm{OH} 43201$

M. D. Boersma

E. I. duPont DeNemours and Company

Savannah River Laboratory

Aiken, SC 29801

Brookhaven National Laboratory

Reference Section

Information Division

Upton, NY 11973

J. L. Crandall

E. I. duPont DeNemours and Company

Savannah River Laboratory

Aiken, SC 29801

R. G. Garvin

E. I. duPont DeNemours and Company

Savannah River Laboratory

Aiken, SC 29801

T. B. Hindman

E. I. duPont DeNemours and Company

Savannah River Laboratory

Aiken, SC 29801 
No of

Copies

$J$ im Howe 1

E. I. duPont DeNemours and Company

Savannah River Laboratory

Aiken, SC 29801

H. L. Hull

E. I. duPont DeNemours and Company

Savannah River Laboratory

Aiken, SC 29801

A. S. Jennings

E. I. duPont DeNemours and Company

Savannah River Laboratory

Aiken, SC 29801

J. A. Kelley

E. I. duPont DeNemours and

Savannah River Laboratory

Aiken, SC 29801

S. Mirshak

E. I. duPont DeNemours and Company

Savannah River Laboratory

Aiken, SC 29801

E. Wilhite

E. I. duPont DeNemours and Company

Savannah River Laboratory

Aiken, SC 29801

H. Henning

Electric Power Research Institute

3412 Hillview Avenue

P. 0. Box 10412

Palo Alto, CA 94301

Environmental Protection Agency

Technology Assessment Division (AW-559)

Office of Radiation Programs

Washington, DC 20460
No of

Copies

R. G. Barnes

General Electric Company

175 Curtner Avenue ( $M / C$ 858)

San Jose, CA 95125

Los Alamos Scientific Laboratory (DOE)

P. 0. Box 1663

Los Alamos, NM 87544

J. P. Duckworth

Plant Manager

Nuclear Fuel Services, Inc.

P. 0. Box 124

West Valley, NY 14171

J. G. Cline, Executive Director Agency B1d.\#2

Empire State Plaza

Albany, NY 12223

Oak Ridge National Laboratory (DOE) Central Research library

Document Reference Section

P. 0. Box X

Oak Ridge, TN 37830

E. H. Kobisk

Solid State Division

Oak Ridge National Laboratory

Oak Ridge, TN 37830

R. Roy

Pennsylvania State University

Materials Research Laboratory

University Park, PA 16802

J. Braithwaite

ORG 5831

Sandia Laboratories

P. 0. Box 5800

Albuquerque, NM 8785

W. Weart

Sandia Laboratories

A1buquerque, NM 87107 
No of

$\underline{\text { Copies }}$

J. 0. Blomeke

Union Carbide Corporation (ORNL)

Chemical Technology Division

P. 0. Box Y

Oak Ridge, TN 37830

R. E. Blanco

Union Carbide Corporation (ORNL)

Chemical Technology Division

P. 0. Box $Y$

Oak Ridge, TN 37830

D. E. Ferguson

Union Carbide Corporation (ORNL)

Chemical Technology Division

P. 0. Box $Y$

Oak Ridge, TN 37830

H. W. Godbee

Union Carbide Corporation (ORNL)

Chemical Technology Division

P. 0. Box Y

Oak Ridge, TN 37830

\section{FORE IGN}

D. W. Clellan

United Kingdon Atomic Energy Authority

Risley, ENGLAND

E. R. Merz

Institu fur Chemische

Kernforschungsan loge Ju lich

$\mathrm{GmbH}$

D5 $\overline{17}$ Julich

Postfach 365

Federal Republic

WEST GERMANY

R. Bonni aud

Center de Marcoule

B. P. 170

30200 Baguols-Sur-Ceze

FRANCE
No of

Copies

C. Sombret

Centre de Marcould

B. P. 170

30200 Baguols-Sur-Ceze

FRANCE

F. Laude

Centre de Marcoule

B. P. 170

30200 Baguols-Sur-Ceze

FRANCE

H. Krause

Kernforschungszentrum Kar lsruhe GmbH (KfK)

Postfach 3640

D7500 Kar lsruhe

WEST GERMANY

S. Tashiron

Japan Atomic Energy Research Institute

Environmental Safety Research Laboratory

1-1-13, Shibashi

Minatipku, Tokyo

JAPAN

2 International Atomic Energy Agency

Kartner Ring 11

P. 0. Box 590

A-1011, vienna, AUSTRIA

B. Morris

Atomic Energy Research

Establishment,

Harwe 11, Didcot,

Berks, ENGLAND

\section{ONSITE}

3 DOE Richland Operations Office

P. A. Craig

H. E. Ransom

M. J. Zamorski 
No. of

Copies

Exxon Nuclear Company

S. J. Beard

5 Rockwell Hanford Operations

L. Brown

M. J. Kupfer

I. E. Reep

D. D. Wodrich

File copy

Westinghouse Hanford Company

A. G. Blasewitz

55 Pacific Northwest Laboratory

S. M. Barnes

W. J. Bjorklund

H. T. Blair

W. F. Bonner

R. A. Brouns

F. L. Buelt

C. M. Devary (3)
No. of

Copies

R. D. Dierks

R. W. Goles

M. S. Hanson

A. J. Haverfield

L. K. Holton

J. H. Jarrett

D. E. Knowlton

D. E. Larson

J. L. McElroy

J. E. Mende 1

F. A. Miller

T. A. Nelson

R. E. Nightingale

K. H. Oma

C. R. Palmer

W. L. Partsin

L. L. Petkus (15)

A. M. Platt

D. L. Prezbindowski (2)

J. M. Rusin

D. H. Siemens

S. C. Slate

C. L. Timmerman

R. T. Treat

Technical Information (5)

Publishing Coordination YO (2) 
